\title{
Dyadic Psychosocial eHealth Interventions: Systematic Scoping Review
}

Kelly M Shaffer ${ }^{1,2}, \mathrm{PhD}$; Ashley Tigershtrom², BA; Hoda Badr ${ }^{3}, \mathrm{PhD}$; Stephanie Benvengo ${ }^{2}$, MA; Marisol Hernandez ${ }^{2,4}$, MLS, MA; Lee M Ritterband ${ }^{1}$, PhD

\author{
${ }^{1}$ Center for Behavioral Health and Technology, University of Virginia School of Medicine, Charlottesville, VA, United States \\ ${ }^{2}$ Memorial Sloan Kettering Cancer Center, New York, NY, United States \\ ${ }^{3}$ Baylor College of Medicine, Houston, TX, United States \\ ${ }^{4}$ CUNY School of Medicine/City College of New York, New York, NY, United States
}

Corresponding Author:

Kelly M Shaffer, $\mathrm{PhD}$

Center for Behavioral Health and Technology

University of Virginia School of Medicine

PO Box 801075

Charlottesville, VA, 22908

United States

Phone: 14349821022

Email: kshaffer@ virginia.edu

\section{Abstract}

Background: Dyadic psychosocial interventions have been found beneficial both for people coping with mental or physical health conditions as well as their family members and friends who provide them with support. Delivering these interventions via electronic health (eHealth) may help increase their scalability.

Objective: This scoping review aimed to provide the first comprehensive overview of dyadic eHealth interventions for individuals of all ages affected by mental or physical illness and their family members or friends who support them. The goal was to understand how dyadic eHealth interventions have been used and to highlight areas of research needed to advance dyadic eHealth intervention development and dissemination.

Methods: A comprehensive electronic literature search of PubMed, EMBASE, Cochrane, Cumulative Index to Nursing and Allied Health Literature, and PsycINFO was conducted for articles published in the English language through March 2019. Eligible records described a psychosocial eHealth intervention that intervened with both care recipients and their support person.

Results: A total of 7113 records were reviewed of which 101 met eligibility criteria. There were 52 unique dyadic eHealth interventions identified, which were tested across 73 different trials. Of the unique interventions, 33 were conducted among dyads of children and their supporting parent, 1 was conducted with an adolescent-young adult care recipient population, and the remaining 18 were conducted among adult dyads. Interventions targeting pediatric dyads most commonly addressed a mental health condition $(n=10)$; interventions targeting adult dyads most commonly addressed cancer $(n=9)$. More than three-fourths of interventions $(n=40)$ required some human support from research staff or clinicians. Most studies ( $n=64)$ specified one or more primary outcomes for care recipients, whereas less than one-fourth $(n=22)$ specified primary outcomes for support persons. Where specified, primary outcomes were most commonly self-reported psychosocial or health factors for both care recipients $(\mathrm{n}=43$ ) and support persons $(\mathrm{n}=18)$. Results of the dyadic eHealth intervention tended to be positive for care recipients, but evidence of effects for support persons was limited because of few studies specifying primary outcomes for supporters. Trials of dyadic eHealth interventions were most commonly randomized controlled trials (RCTs; $n=44)$, and RCTs most commonly compared the dyadic eHealth intervention to usual care alone $(n=22)$.

Conclusions: This first comprehensive review of dyadic eHealth interventions demonstrates that there is substantial, diverse, and growing literature supporting this interventional approach. However, several significant gaps were identified. Few studies were designed to evaluate the unique effects of dyadic interventions relative to individual interventions. There was also limited assessment and reporting of outcomes for support persons, and there were no interventions meeting our eligibility criteria specifically targeting the needs of older adult dyads. Findings highlight areas of research opportunities for developing dyadic eHealth interventions for novel populations and for increasing access to dyadic care. 
(J Med Internet Res 2020;22(3):e15509) doi: 10.2196/15509

\section{KEYWORDS}

behavioral medicine; caregivers; couples therapy; dyads; eHealth; family therapy; internet interventions; psychosocial interventions; review

\section{Introduction}

\section{Background}

Psychosocial interventions provide evidence-based behavioral, cognitive, and emotion regulation strategies to address mental and physical health conditions. These conditions not only affect the person diagnosed with illness but also their close family members and friends, particularly those who support the clinical care of the person with illness. Dyadic interventions that intervene with both the care recipient and their support person together have been found clinically useful [1-5]; however, most have been designed to be delivered in-person, limiting their ultimate scalability and accessibility [6]. Delivering dyadic interventions via electronic health (eHealth; ie, using information communication technologies to facilitate health care provision) may increase their uptake by overcoming structural and financial access barriers. A broad review of the literature on dyadic eHealth interventions is needed to better understand how these interventions have been used and to identify where further research is needed.

\section{Illness Affects Dyads Together}

It is estimated that 43.5 million Americans provide informal, unpaid care to one or more adults or children with serious health conditions [7]. Of these, it is estimated that about 33.3 million provide such care to adult recipients only, 3.7 million to child recipients only, and 6.5 million to both adult and child recipients. About $15 \%$ of people who provide care are not legally defined family members of the care recipient (eg, friend or neighbor [7]), and many individuals do not identify with the term caregiver (eg, [8]). As such, the term support persons is used for this scoping review to broadly capture individuals who provide emotional and practical support to help a care recipient. Together, the support person and the care recipient comprise a dyad.

Support from family members and friends to seriously ill individuals is critical to the sustainability of the US health care system [9], yet it can place significant strain on these support persons. Compared with the general population, support persons report worse diet, exercise, and sleep [10-12]; worse symptoms of depression and anxiety [13-15]; and premature physical health decline [16-18]. These mental and physical burdens from caregiving also ultimately affect the care recipients. Distressed support persons are more likely to exhibit harmful caregiving behavior [19] and less able to meet the practical and social-emotional needs of the care recipient $[20,21]$. When one dyad member is distressed, the other is more likely to become distressed as well [22-25]. Care recipients and their support persons experience illness together, and the success of one person's ability to cope with illness stressors affects the other's [26-28].

\section{Intervening With Dyads}

Dyadic interventions may use a range of strategies, such as communication skills training, cognitive behavioral therapy, education, and problem-solving training. These interventions share the commonality of including both the care recipient and their support person together within a singular program of care. Dyadic psychosocial interventions have been found effective to improve targeted outcomes for both care recipients and support persons [1-5,29,30]. As coping is interdependent between care recipients and support persons, there is promise that dyadic interventions may deliver synergistic benefits-meaning the cumulative benefits to both individuals from a dyadic intervention is greater than the sum of benefits of intervening with each member individually. In practice, there has been limited empirical study of such effects [1,30].

Even if there are no such synergistic effects, dyadic interventions may be an attractive way to extend psychosocial care access to support persons. Interventions specifically addressing support persons' informational and psychosocial needs have rarely been implemented in health care settings-common institutional barriers include competing clinical demands and lack of funding [31]. Support persons tend to underutilize available caregiver-directed programs, in part because of a reluctance to put their needs ahead of those of the care recipient [32,33]. Dyadic interventions may therefore be perceived as more justifiable by both health care systems and support persons: the care recipient is a target of care, and support persons receive care as well.

Despite the promise of dyadic interventions, there are significant logistical and financial barriers impeding their dissemination [6]. Common practical barriers like scheduling difficulties and limited time [32-36] are compounded when both care recipients' and support persons' schedules must align. In addition, support persons often have inadequate health care coverage [37], meaning that obtaining such care is likely to be cost-prohibitive for many dyads. Disseminating dyadic interventions via the internet and other technologies may lower the barrier to entry and increase their affordability [38]. The internet fills an important gap in meeting health information needs [39], and this is particularly true for support persons, who are more likely than noncaregivers to seek health information on the Web [40]. Internet- and technology-based approaches are also more scalable from a health systems perspective: reduced labor costs, as well as minimal ongoing program costs, suggest the long-term cost-efficacy of eHealth interventions relative to traditional face-to-face care [41].

\section{Purpose of This Review}

The aims of this scoping review were twofold. The first aim was to provide the first summary of available evidence on dyadic eHealth interventions that provide behavioral treatment and/or psychosocial support to care recipients of all ages affected by 
any mental or physical illness together with their primary support persons. The second aim was to identify gaps in this knowledge base. To date, there has been one pioneering review of dyadic eHealth programs among cancer survivors and their family caregivers [29]. There have been many reviews demonstrating the efficacy and acceptability of eHealth interventions among diverse populations of patients (eg, [42-55]) and support persons (eg, [56-68]). All of these reviews have summarized literature within certain disease or age group populations, which silos the literature. In contrast, this review is intentionally broad, summarizing the literature across care recipient health conditions (eg, mental health, obesity, and cancer), population subgroups (eg, pediatric and adult care recipients), and intervention strategies (eg, communication training and cognitive behavioral therapy). Aims were well suited to a scoping review, which are ideal for reviewing a large and complex body of research that has not been previously reviewed $[69,70]$. The specific research questions that guided this review were as follows:

1. What populations have been targeted by dyadic eHealth interventions?

2. How have information communication technologies been used in dyadic eHealth interventions?

3. What approaches are used for intervening with both dyad members?

\section{Methods}

A comprehensive electronic literature search for articles in the English language and for all available dates was conducted in the following databases: PubMed, EMBASE via the Elsevier platform, Cochrane via the Wiley platform, Cumulative Index for Nursing and Allied Health Literature via EBSCO and PsycINFO via the OVID platform.

\section{Eligibility Criteria}

Population, Intervention, Comparison, Outcome, Study design criteria (PICOS [71]) that guided study selection and organization of data extraction for this systematic scoping review are detailed below.

\section{Population}

Eligible studies enrolled dyads of care recipients and support persons. The care recipient is a person who has an identified mental, behavioral, or physical health condition. The support person provides informal, unpaid care to the care recipient. Dyads are defined by existing, personal relationships like kinship or friendship, meaning that dyads of care recipients with a formal, trained health care provider (eg, their physician or an assigned trained peer mentor) were excluded. There could be more than one support person in a dyad-for example, a child with illness participating with both parents could be a dyad. There was no restriction on age of the dyad members, provided that the individual could consent or assent to participate.

\section{Intervention}

There were 3 intervention-related inclusion criteria that defined eligible dyadic eHealth interventions. First, an intervention must have intervened with both members of the dyad. Second, drawing from prevailing definitions of eHealth [72,73] and internet interventions [74], an intervention must have utilized information communication technology (including, but not limited to, the internet), with at least some intervention content delivered fully automated. Owing to this criterion, interventions that exclusively utilized technology to deliver standard clinician-provided care (eg, a therapist providing face-to-face therapy via video chat) were excluded. Third, an intervention must have provided cognitive, behavioral, educational, and/or supportive care with the primary goal to address symptom management and/or coping with the care recipients' targeted health condition. Owing to this criterion, couples therapy that intervenes with the primary goal of improving the couple's relationship was excluded.

\section{Outcome}

Records were included if they reported any objective or self-report psychosocial, health, and/or feasibility outcome for the care recipient and/or the support person. Outcomes were specified as primary if they were explicitly labeled as such in the record or hypotheses were explicitly specified about the outcome. Outcomes were specified as (1) an objective psychosocial or health measure, such as data derived via lab test (eg, hemoglobin $\mathrm{A}_{1 \mathrm{c}}$ ), diagnostic interview (eg, structured clinical interview for Diagnostic and Statistical Manual of Mental Disorders-5), or chart review (eg, documented family meeting); (2) a self-report psychosocial or health measure, such as data derived via self-reported questionnaire; or (3) a feasibility/usability measure, which may have been objective (eg, website logins) or self-reported (eg, satisfaction).

\section{Study Design and Comparators}

All trial designs were eligible for inclusion, including single-arm trials, feasibility trials, patient preference trials (ie, care recipient could enroll in an intervention with or without a support person), and randomized controlled trials (RCTs). There was no restriction on the type of comparison condition in RCTs. For the purposes of this review, waitlist control conditions are included under the umbrella of usual care. All study analytic designs were eligible for inclusion, including records that reported long-term follow-ups and secondary analyses of trial data. Records that exclusively discussed intervention development, but did not report testing of the intervention as it was intended to be used, were excluded.

\section{Search Methodology for Identification of Studies}

The search was initially conducted by MH in January 2018 and an update was conducted in March 2019. Three broad concept categories were searched (dyads, eHealth, and psychosocial intervention), and results were combined using the appropriate Boolean operators (AND, OR). See Table 1 for search strategy. Potentially eligible records were also identified through other sources, such as via review of references of included records, communication with record authors, and a hand search of Journal of Medical Internet Research publications. 
Table 1. Search strategy.

\begin{tabular}{|c|c|}
\hline $\begin{array}{l}\text { Concept category (combined } \\
\text { with AND) }\end{array}$ & Search terms (combined with OR) \\
\hline Dyads & $\begin{array}{l}\text { dyad, dyads, dyadic, couple, couples, spouse, spouses, "Spouse"[MeSH], partner, partners, "Sexual Partners"[MeSH], } \\
\text { parent, parents, "Parents" [MeSH], parental, guardian, guardians, "Legal Guardians"[MeSH], child, "Child"'[MeSH], } \\
\text { children, kid, kids, adolescent, adolescents, "Adolescent"[MeSH], teen, teens, teenager, teenagers family, families, } \\
\text { "Family"[MeSH], informal caregiver, caregiver, "Caregivers"[MeSH], carer, carers }\end{array}$ \\
\hline eHealth & $\begin{array}{l}\text { Internet, "Internet"[MeSH], cyberspace, web, web-based, ehealth, e-health, "Telemedicine"[MeSH], mobile health, } \\
\text { mhealth, m-health, social media, "Social Media" }[\mathrm{MeSH}] \text {, blog, blogs, mobile app, mobile application, User-Computer } \\
\text { Interface, website, webpage }\end{array}$ \\
\hline Psychosocial intervention & $\begin{array}{l}\text { "Behavioral Medicine" }[\mathrm{MeSH}] \text {, psychosocial intervention, behavior therapy, "Behavior Therapy" }[\mathrm{MeSH}] \text {, cognitive } \\
\text { therapy, "Cognitive Behavioral Therapy" }[\mathrm{MeSH}] \text {, couples therapy, "Couples Therapy”"[MeSH], family therapy, } \\
\text { "Family Therapy"[MeSH], psychoeducation, psycho-education psychoeducational, psycho-educational, "Psychology, } \\
\text { Medical"[MeSH], "Psychology, Clinical"[MeSH] }\end{array}$ \\
\hline
\end{tabular}

\section{Study Selection}

After removal of duplicate articles, study titles and abstracts were scanned by 2 of 3 coders (KS, AT, and SB) to determine whether the study met eligibility criteria. Discrepancies between coders were reviewed at a consensus meeting of all 3 coders. $\mathrm{AT}$ and SB retrieved full-text articles for citations that initially met the eligibility criteria. Full-text articles were read by KS, AT, or SB to make a final determination of eligibility, with ongoing coding questions reviewed at regular coder consensus meetings. Title/abstract and full-text coding were conducted using Covidence systematic review software (Veritas Health Innovation, Australia) [75]. Coders were not blind to journals or study authors during screening.

Reasons for article exclusion during the full-text review were recorded. Exclusion criteria based on PICOS criteria were (1) Not dyadic - an intervention did not intervene with a care recipient and informal support person to address the care recipient's health condition; (2) intervention development, protocol, and/or no psychosocial, health, or feasibility outcome reported; (3) no automated components; (4) prevention study — neither dyad member had an indicated health condition at the time of enrollment (ie, there was no care recipient). There was 1 conference abstract that passed title/abstract screening based on review of its title, but the full abstract text was not retrievable from databases, the conference organization, or the authors. Authors indicated that abstract results were reported in a journal article of the same name, which was included in full-text coding.

\section{Data Extraction}

Coders (AT and a trained research assistant) extracted data from the records that met eligibility criteria. Data were collected using a standardized, predefined charting form via Qualtrics. KS checked all extractions after completion by the coders.
Discrepancies were resolved by tertiary review by SB, who discussed findings with $\mathrm{KS}$. Articles were not blinded during data extraction. Corresponding authors for all articles were contacted and asked to review data extracted from their articles. Data were then summarized, and themes were reviewed.

\section{Results}

\section{Overview}

The Preferred Reporting Items for Systematic Reviews and Meta-Analyses [76] flow diagram is presented in Figure 1. In total, 7113 records were identified via the search terms, and 14 were identified through other sources (including email responses from contacted authors), of which 573 were retrieved and reviewed for full-text coding. Of these, 101 records met eligibility criteria and were included in the qualitative synthesis. Data extraction is represented in Multimedia Appendix 1 [77-95,111,115-195], as well as in sortable worksheets available through the Open Science Framework by the Center for Open Science on its website [196].

Included records were published as early as 2003 [77,78]. There is a noted acceleration in the numbers of records published over the past 10 years: 22 records were published from 2003 to 2010 , and 79 were published from 2011 through March 2019. Most records were full-text manuscripts $(93 / 101,92.1 \%)$. Across records, there were 73 unique trials -1 record [79] reported 2 separate trials. Trials were most commonly conducted in the United States (37/73, 51\%), with 14 in Sweden (19\%), 10 conducted in Australia (14\%), and 4 in Canada (5\%), among other countries of origin. In total, there were 52 unique dyadic eHealth interventions identified. The following sections present summarized findings related to study population, intervention system components, and study outcomes and design characteristics. 
Figure 1. Preferred Reporting Items for Systematic Reviews and Meta-Analyses flow diagram.

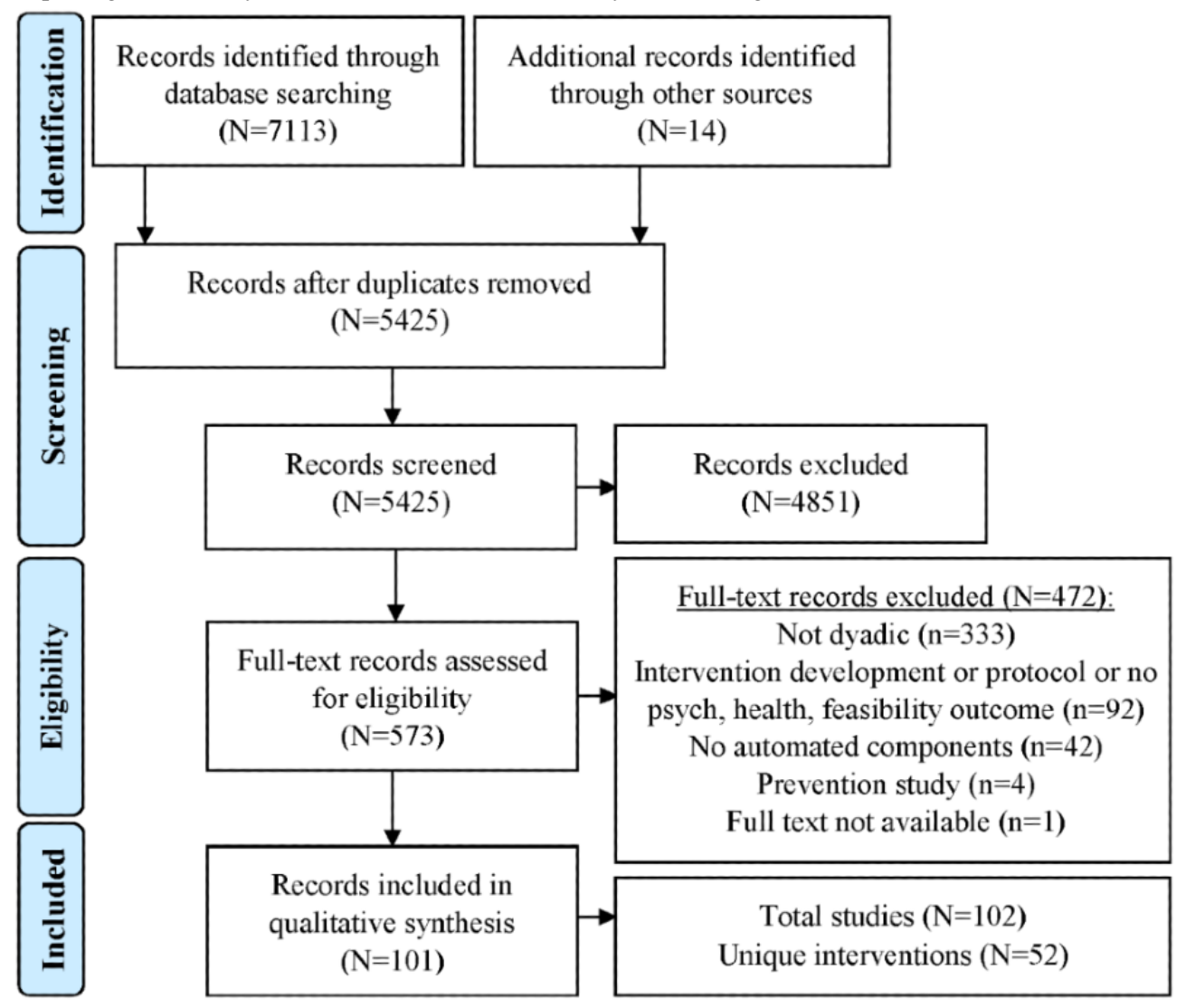

\section{Populations}

A total of 72 records reported results from 52 trials of 33 unique dyadic eHealth interventions that targeted dyads in which the care recipient was a minor. For all of these trials, it was specified that a parent/guardian must be the support person. Only 1 trial $[80,81]$ did not require that a parent/guardian participate in order for the child to participate-all other trials did require a parent/guardian to participate. These interventions most commonly targeted the care recipient's mental health condition $(10 / 33,30 \%)$. Other conditions targeted included obesity $(8 / 33$, $24 \%)$, gastrointestinal disorders $(4 / 33,12 \%)$, pain conditions $(3 / 33,9 \%)$, and traumatic brain injury $(2 / 33,6 \%)$. In all, 3 trials targeted dyads including care recipients with 2 specific comorbidities. Conaughton et al [82] tested a transdiagnostic internet-delivered cognitive behavioral therapy for anxiety program among children with both an anxiety disorder and high functioning autism spectrum disorder; Lee et al [83] developed an mHealth program to address weight management among children with both overweight/obesity and intellectual disability; and Palermo et al [84] tested a Web-based program for children with chronic pain and sickle cell disease.

Only 1 record reported results from 1 trial of 1 intervention that specifically recruited an adolescent-young adult population (ie, care recipients ranged from mid-teens through early 30s [85]). The support person could be any close individual (eg, family member, romantic partner, or nonrelative) and was not required to enroll in order for the care recipient to participate. This study targeted care recipients who required catheterization.
A total of 28 records reported results from 21 trials of 18 interventions in which the care recipients were exclusively adults (ie, aged 18 years or older). Six of these trials $(6 / 21,29 \%)$ targeted recruitment to dyads of spouses/romantic partners; in the remaining 15 trials $(15 / 21,71 \%)$, the support person could be any close individual. Of note, the 3 trials of the CarePartner intervention [86-90] required that the participating support person reside outside the care recipient's home. In all, 11 of the $21(52 \%)$ trials of adult dyadic eHealth interventions required that both the care recipient and the support person enroll together for either to participate. Adult dyadic eHealth interventions most frequently targeted care recipients with cancer $(9 / 18,50 \%)$. Other conditions targeted included mental health conditions $(3 / 18,17 \%)$ and diabetes $(2 / 18,11 \%)$. Two trials targeted dyads including care recipients with 2 specific comorbidities. Both Schover et al [91] and Hummel et al [92,93] tested internet-based interventions addressing sexual dysfunction secondary to cancer.

\section{Intervention Information}

\section{Intervention System Components}

Interventions tended to deliver content, intervene, and engage users through multiple components: the median number of components was $3(M=3.03)$, ranging from 1 to 6 components. The 3 most commonly utilized components were browser-based components, human telephone contact, and asynchronous communication portals. Browser-based components, or webpages, were used in 44 of $52(85 \%)$ interventions. Human telephone contact, most commonly contact with a therapist or research staff person, was used in 25 interventions $(25 / 52,48 \%)$. Asynchronous communication portals, most commonly used 
to contact a therapist, research staff person, or other intervention participants via a communication portal embedded within the program such as encrypted email portal or a discussion board, were used in 22 interventions $(22 / 52,42 \%)$.

A total of 40 interventions $(40 / 52,77 \%)$ required human support as they included a component that required therapist or research staff effort (ie, videoconferencing, human telephone contact, human emails/SMS, asynchronous communication portal, synchronous chat room, or in-person sessions).

\section{Dyad Participation and Content Target}

In all, 21 interventions were intended to be used entirely separately by care recipients and support persons $(21 / 52,40 \%)$. Interventions were almost as commonly intended to be used with care recipients and support persons accessing some aspects of the intervention together and other aspects separately (20/52, $38 \%$ ). Fewer interventions were intended to be used by the dyad entirely together $(6 / 52,12 \%)$. In some cases $(5 / 52,10 \%)$, it was not specified how an intervention was intended for use by care recipients and support persons-either because it was unspecified in the record or because there was no specific way that dyads were expected to interact with the intervention.

Most interventions $(38 / 52,73 \%)$ had content that was exclusively intended to be accessed by support persons, and most had content that was exclusively intended to be accessed by care recipients $(38 / 52,73 \%)$. A total of 32 interventions $(32 / 52,62 \%)$ had shared content that was accessible to both the care recipients and support persons. In all, 14 interventions $(14 / 52,27 \%)$ included all 3 types of content (ie, for care recipients only, for support persons only, and shared).

\section{Outcomes, Study Design, and Comparators}

Most studies $(63 / 102,61.8 \%)$ specified one or more primary outcomes for care recipients and 22 of 102 (21.6\%) specified one or more primary outcomes for support persons. In all, 6 studies $(6 / 102,5.9 \%)$ reported no outcomes for care recipients and $35(35 / 102,34.3 \%)$ reported no outcomes for support persons. Among the 63 studies specifying primary outcomes for care recipients, $23(37 \%)$ included objective primary psychosocial or health outcomes, $43(68 \%)$ included self-report primary psychosocial or health outcomes, and $3(5 \%)$ included feasibility/usability primary outcomes (see Methods, Eligibility Criteria, Outcome section for definitions). Among the 33 studies specifying other outcomes for care recipients, 7 (21\%) included objective outcomes, 14 (42\%) included self-report outcomes, and $26(79 \%)$ included feasibility/usability outcomes. Among the 22 studies specifying primary outcomes for support persons, $3(14 \%)$ included objective primary outcomes, $18(82 \%)$ included self-report primary outcomes, and $2(9 \%)$ included feasibility/usability primary outcomes. Among the 46 studies specifying other outcomes for support persons, 1 (2\%) included objective outcomes, 21 (46\%) included self-report outcomes, and 34 (74\%) included feasibility/usability outcomes.

Trials of dyadic eHealth interventions were most commonly RCTs (44/73, 60\%). Among the 44 RCTs, most (22/44, 50\%) compared the dyadic eHealth intervention with usual care alone; $8(18 \%)$ with an educational website or internet-delivered resources; 4 (9\%) with an in-person version of the intervention;
$2(5 \%)$ with an intervention delivered exclusively to the care recipients (ie, no support person intervention); 2 (5\%) with an intervention delivered exclusively to support persons (ie, to parents alone); and 6 (14\%) with another kind of intervention. Less common study designs were single-arm trials $(23 / 73,32 \%)$, patient preference trials $(3 / 73,4 \%)$, parallel-group RCTs $(2 / 73$, $3 \%)$, or observational studies $(1 / 73,1 \%)$.

Among studies from RCTs that specified one or more primary outcomes for care recipients, 95\% (19/20) of dyadic eHealth interventions demonstrated at least one or more statistically superior outcomes compared with usual care and $20 \%$ (1/5) with an educational website or internet-delivered resources. Positive findings for primary outcomes were found in a trial comparing a combination of 2 interventions with either of the singular interventions. In all, 2 RCTs compared a dyadic eHealth intervention with a parent-only eHealth intervention: 1 trial demonstrated better outcomes for care recipients in the dyadic condition [94] and 1 trial demonstrated better outcomes for care recipients in the parent-only condition [95]. There were no significant differences for any care recipient primary outcomes when dyadic eHealth interventions were compared with an in-person version of the intervention ( $\mathrm{n}=3$ trials), an intervention delivered exclusively to the care recipients $(n=1)$, or another kind of intervention $(\mathrm{n}=2)$.

Among RCTs that specified one or more primary outcomes for support persons, $60 \%$ (3/5) of dyadic eHealth interventions demonstrated at least one or more statistically superior outcomes compared with usual care and $67 \%$ (2/3) with an educational website or internet-delivered resources. In 1 trial, parents' involvement in their child's care was superior among parents in a parent-only intervention relative to the dyadic intervention [95]. There were no significant differences for any support person primary outcomes when dyadic eHealth interventions were compared with an in-person version of the intervention $(n=2$ trials) or another kind of intervention $(n=1)$.

Among single-arm trials that compared preintervention to postintervention levels of one or more specified primary outcomes, 93\% (13/14) showed at least one significantly improved outcome for care recipients and 100\% (3/3) for support persons. The 1 patient preference trial that specified primary outcomes demonstrated better outcomes for care recipients who elected to enroll with a support person compared with those who enrolled by themselves [88].

\section{Discussion}

\section{Principal Findings}

This review provides the first comprehensive summary of dyadic interventions utilizing eHealth approaches to provide psychosocial care to care recipients and their support persons together as a unit. Three research questions guided the review: what populations had been targeted by these interventions, how technologies have been utilized in these interventions, and approaches these interventions have taken to intervene with the dyad. Of over 7000 reviewed records, 101 met eligibility criteria and described 52 unique dyadic eHealth interventions. In all, 33 of the unique interventions were conducted among dyads of 
children and their supporting parent, and 18 of the interventions were conducted among adult dyads with diverse relationships. Less than one-fourth of all interventions were fully automated. When a primary outcome was specified, the results of the dyadic eHealth intervention tended to be positive for both care recipients and support persons, although less than one-fourth of studies specified a primary outcome for support persons. One-third reported no outcomes for support persons at all.

This review reveals that there is substantial, diverse, and growing literature supporting dyadic eHealth interventions. This robust literature demonstrates a broad range of strategies for delivering interventions to dyads via eHealth and also identifies several significant gaps in the science. By summarizing broadly across the literature, findings highlight areas of research opportunities for developing dyadic eHealth interventions for novel populations and increasing access to dyadic care. Findings also demonstrate broad variability in approaches of intervening with dyads, with open questions remaining regarding the necessary and sufficient components that define a dyadic intervention.

\section{Populations Targeted by Dyadic Electronic Health Interventions}

The literature base for pediatric dyadic eHealth interventions was relatively more established compared with the more nascent rise in dyadic eHealth interventions for adult dyads. There were almost twice as many unique eHealth interventions and trials for parent-child dyads compared with those for dyads with adult care recipients. Only 2 of 18 adult dyadic eHealth interventions had been tested in more than 1 trial. This is compared with 7 of 33 pediatric dyadic eHealth interventions that were tested in more than 1 trial, and 3 interventions were tested in 4 or more trials. This discrepancy may be due in part to the fact that pediatric dyadic eHealth interventions started to be published much earlier than adult interventions: about one-fourth of the pediatric records were published before 2010, whereas only 2 records on an adult dyadic eHealth intervention were published before 2010. This finding also reflects the more long-standing emphasis on family-centered care in pediatric health care [96-98] and the increasing acceptance of family-centered care among adult health care delivery [99-101].

There was also a discrepancy between pediatric and adult dyadic eHealth interventions in terms of the care recipient conditions targeted by the interventions. Although over half of adult dyadic eHealth interventions addressed coping with the care recipients' cancer treatment and side effects, there were no pediatric interventions specifically addressing cancer. In contrast, pediatric interventions commonly targeted obesity and pain, whereas no adult interventions targeted these specific conditions. Cancer, obesity, and chronic pain affect individuals of all ages and their families and are strongly influenced by heritable and shared lifestyle factors within families. As such, it is worth considering how dyadic eHealth interventions might be extended to address pediatric and adolescent/young adult cancer survivorship, as well as obesity and chronic pain among adults.

One population notably missing from representation is older adult dyads (eg, care recipients and/or support persons over age 65 years). In the context of our eligibility criteria, no interventions were specifically tailored to older adult needs, no trials recruited an exclusively older adult population, and no records specifically reported intervention effects among older participants. Older adult care recipients are most likely to be cared for by their spouses who frequently have health limitations of their own [7], meaning that dyadic care is particularly important for older adults. Older support persons are as interested in eHealth resources as younger support persons [102]. In actual practice, however, older support persons are less likely to access internet-based caregiving resources than younger ones [103,104]. This discrepancy may in part be because of older adults having difficulty navigating eHealth resources [105], which emphasizes the importance of developing dyadic eHealth tools specifically with older users in mind.

\section{Use of Electronic Health Technologies}

Technology that automates care is integral to extend the reach of dyadic interventions by overcoming current logistical and financial barriers $[6,38,106]$. More than three-fourths of dyadic eHealth interventions identified in this review, however, utilized human support. In addition, 2 of the 3 most commonly used intervention system components require human support (ie, by telephone or asynchronous communication portal). Human involvement was not always extensive. For instance, with Web-based Management of Adolescent Pain, Palermo et al [84] report expressly instructing therapists to spend no more than 5 min to respond to a participant message. Importantly, such minimal human support may be sufficient to enhance clinical outcomes: in one of their studies, Anderson et al [79] demonstrated that dyads of anxious youths and their parents reported comparable working alliance with their therapist in a minimal-touch Web-based version of an intervention as dyads receiving the intervention in traditional face-to-face care.

There may be important rationale to include human support in a dyadic eHealth intervention, such as to increase perceived acceptability, user engagement, and clinical outcomes [107-109]. Progressing capabilities of technology to provide automated and personalized feedback, however, suggest that discrepancies in implementation and clinical outcomes will continuously narrow between human-supported and automated interventions $[38,110]$. Indeed, it appears that dyads may vote with their feet toward increasing automation-Schover et al [91] reported that their recruitment rate tripled when dyads were guaranteed access to a Web-based intervention as opposed to being randomized between the Web-based intervention or to the same intervention content delivered by telephone with a nurse. In their pilot of a Web-delivered adaptation of a previously nurse-delivered coping program, Northouse et al [111] found that enrollment rates for the Web version were lower than enrollment rates into prior trials for the nurse-delivered version; however, the retention rate for the Web version was higher than retention rate for the nurse-delivered version. As technological capacity-and society's expectations for it-increase, the relative advantages of clinician support compared with highly responsive technologies should be carefully considered to ensure greatest efficacy and reach of dyadic interventions. 


\section{Approaches to Intervening With the Dyad}

In this review, we utilized a broad definition to identify dyadic interventions-namely, an intervention that intervened with both a care recipient and (at least one) informal support person to provide comprehensive treatment for the care recipient's health condition. About 1 in 4 identified dyadic eHealth interventions appeared to address the unique needs of each individual in the dyad, while also addressing relational factors between the dyad. These interventions both (1) included content that was uniquely tailored for and exclusively accessible by care recipients and support persons separately, in addition to shared content available to both users; and (2) were either intended to be utilized both together and separately or left up to the dyads how to interact with the intervention. Addressing relational factors between dyad members is likely a key element to delivering synergistic benefits beyond those from individual interventions, as they enhance natural support between dyad members [112-114]. Previous literature suggests that dyadic interventions addressing these relational aspects of coping with illness are more effective than primarily informational interventions [4].

An example of a dyadic eHealth intervention that addresses both individual needs and the dyadic relationship is the Schizophrenia Online Access to Resources intervention [115-117]. This intervention addresses unique concerns of both dyad members - for example, with unique therapy forums for the individuals with schizophrenia only and support persons only, as well as addressing shared skills for the whole family_for example, shared content regarding developing a supportive safety net together. Across their manuscripts, Rotondi et al [115-117] establish rationales for the use of dyadic and eHealth approaches: a dyadic approach was utilized because family-based therapy is the gold standard for schizophrenia, given the detrimental effects of a stressful family environment on worsening patients' symptom severity. An eHealth approach was utilized given that traditional in-person family-based schizophrenia interventions have had low uptake and retention, and authors reasoned that eHealth programs would be more accessible to families affected by schizophrenia.

\section{Limitations and Future Directions}

There are limitations to both the body of literature summarized and the methods we used to summarize this literature. Regarding the former, less than two-thirds of the 52 unique dyadic eHealth interventions have been tested for efficacy in an RCT. Among RCTs, over half compared against usual care or waitlist control alone. Although the usual care comparator may be an important first step toward demonstrating clinical benefits of an intervention, these trials leave important questions about the unique benefits of dyadic interventions unanswered. For example, trials are needed that compare outcomes for both patients and support persons when provided a dyadic eHealth intervention versus individual eHealth interventions for patients and for support persons alone. Such trials would begin to demonstrate whether, and under what circumstances, dyadic eHealth interventions are superior to individually delivered interventions. eHealth interventions are better suited for such trials than face-to-face interventions, given large-scale recruitment is more feasible. In addition, participants can be randomized to receive only part of a larger intervention: for instance, 1 dyad receives the full dyadic eHealth intervention, whereas in another dyad, only the support person receives applicable content from the full intervention. These data will be necessary to justify the added costs and complication of intervening with both care recipients and support persons together.

Another substantial limitation of this literature is the fact that one-third of all studies reported no outcomes for support persons. This issue was identified in one of the earliest reviews of dyadic psychosocial interventions published almost 15 years ago [1]. It is possible that support person outcome data were collected but not reported in these records. Regardless, omitting support person data is a significant missed opportunity to demonstrate the effects of an intervention to roughly half of its users. Given the extensive care responsibilities support persons already assume and the psychosocial and physiological strain of those responsibilities, intervention developers should carefully consider whether the benefits of including a support person in an intervention ultimately outweigh the costs to that support person. Reporting outcomes for support persons are critical to demonstrate that these interventions, at minimum, do no harm to them.

Although the breadth of this review is a strength, the lack of common vocabulary and established criteria that define dyadic interventions made this review challenging to complete. Pediatric interventions, in particular, may be more commonly described as family based rather than dyadic. To best ensure we captured all interventions that met our broad definition of dyadic eHealth interventions, we carefully developed a search strategy with our medical librarian. It remains possible, however, that we missed interventions that meet our core definitional qualities of dyadic eHealth interventions but use a different vocabulary. Ultimately, to advance the science on dyadic interventions, reaching consensus on ideal qualities of dyadic interventions will be helpful to guide development, assessment, and dissemination of this model of care.

In addition, as a scoping review covering broad literature, we were limited to capturing only superficial components of these interventions. In particular, we were unable to more extensively describe the nature of content delivered by the interventions, which would afford a more nuanced understanding of how interventions address dyad members' unique needs and their relational needs. Given the breadth of data extracted from the volume of records, we also were unable to present detailed results related to study outcomes and designs across subsets of populations, health conditions, or strategies. Finally, we did not extract sample sizes from the studies or location where the intervention was received by participants (eg, home and health care facility). Ideally, this review highlights the breadth of the dyadic eHealth literature and the opportunities for more specific systematic reviews on pertinent subtopics.

\section{Conclusions}

This first comprehensive review of dyadic eHealth interventions identified the substantial and rapidly growing literature describing the use of these interventions across a broad range 
of populations. Collating this robust literature will hopefully serve as a resource for intervention developers to identify models most likely to be effective given the goals and requirements of a particular intervention, rather than models that have been typically used within a particular population. Although the literature on dyadic eHealth interventions is robust, there are significant gaps. For instance, few studies reported outcomes for support persons, data which are essential to justifying their inclusion in interventions. Other gaps highlight important future research needs: for instance, development of interventions designed for older adults and trials comparing the relative efficacy of dyadic and individual eHealth interventions. As technology advances, further personalizing and automating dyadic eHealth interventions will help to increase their scalability, and ultimately, their likelihood of benefitting all who are affected by illness.

\section{Acknowledgments}

The authors sincerely thank David Vann for his contributions to data extraction and to the authors of the included studies who assisted this effort by reviewing data extracted from their trials. KS was supported by grant \#IRG 81-001-26 from the American Cancer Society, as well as T32-CA009461 (PI: Ostroff) and Cancer Center Support Grant P30-CA008748 (PI: Thompson) from the National Cancer Institute.

\section{Conflicts of Interest}

None declared.

\section{Multimedia Appendix 1}

Study Information.

[PDF File (Adobe PDF File), 635 KB-Multimedia Appendix 1]

\section{References}

1. Martire LM. The 'Relative' efficacy of involving family in psychosocial interventions for chronic illness: are there added benefits to patients and family members? Fam Syst Health 2005;23(3):312-328. [doi: 10.1037/1091-7527.23.3.312]

2. Martire LM, Schulz R. Involving family in psychosocial interventions for chronic illness. Curr Dir Psychol Sci 2007;16(2):90-94. [doi: 10.1111/j.1467-8721.2007.00482.x]

3. Martire LM, Lustig AP, Schulz R, Miller GE, Helgeson VS. Is it beneficial to involve a family member? A meta-analysis of psychosocial interventions for chronic illness. Health Psychol 2004 Nov;23(6):599-611. [doi: 10.1037/0278-6133.23.6.599] [Medline: 15546228$]$

4. Hartmann M, Bäzner E, Wild B, Eisler I, Herzog W. Effects of interventions involving the family in the treatment of adult patients with chronic physical diseases: a meta-analysis. Psychother Psychosom 2010;79(3):136-148. [doi: 10.1159/000286958] [Medline: 20185970]

5. Stahl ST, Rodakowski J, Saghafi EM, Park M, Reynolds CF, Dew MA. Systematic review of dyadic and family-oriented interventions for late-life depression. Int J Geriatr Psychiatry 2016 Sep;31(9):963-973 [FREE Full text] [doi: 10.1002/gps.4434] [Medline: 26799782]

6. Ratcliff CG, Vinson CA, Milbury K, Badr H. Moving family interventions into the real world: what matters to oncology stakeholders? J Psychosoc Oncol 2019;37(2):264-284. [doi: 10.1080/07347332.2018.1498426] [Medline: 30421667]

7. National Alliance for Caregiving, AARP Public Policy Institute. AARP Public Policy Institute. 2015. Caregiving in the US URL: https://www.aarp.org/content/dam/aarp/ppi/2015/caregiving-in-the-united-states-2015-report-revised.pdf [accessed 2020-01-03]

8. Amaro LM. Convincing family caregivers to participate in research: 'Does that count as caregiving?'. J Appl Commun Res 2015;43(2):269-272. [doi: 10.1080/00909882.2015.1019547]

9. Reinhard S, Feinberg L, Choula R, Houser A. AARP Public Policy Institute. 2015 Jul. Valuing the Invaluable: 2015 Update URL: https://www.aarp.org/content/dam/aarp/ppi/2015/valuing-the-invaluable-2015-update-new.pdf [accessed 2020-01-03]

10. Chassin L, Macy JT, Seo D, Presson CC, Sherman SJ. The association between membership in the sandwich generation and health behaviors: A longitudinal study. J Appl Dev Psychol 2010 Jan 1;31(1):38-46 [FREE Full text] [doi: 10.1016/j.appdev.2009.06.001] [Medline: 20161605]

11. Hoffman GJ, Lee J, Mendez-Luck CA. Health behaviors among Baby Boomer informal caregivers. Gerontologist 2012 Apr;52(2):219-230 [FREE Full text] [doi: 10.1093/geront/gns003] [Medline: 22391873]

12. Morris BA, Thorndike FP, Ritterband LM, Glozier N, Dunn J, Chambers SK. Sleep disturbance in cancer patients and caregivers who contact telephone-based help services. Support Care Cancer 2015 Apr;23(4):1113-1120. [doi: 10.1007/s00520-014-2458-y] [Medline: 25297467]

13. Butler SS, Turner W, Kaye LW, Ruffin L, Downey R. Depression and caregiver burden among rural elder caregivers. J Gerontol Soc Work 2005;46(1):47-63. [doi: 10.1300/J083v46n01_04] [Medline: 16338884]

14. Cochrane JJ, Goering PN, Rogers JM. The mental health of informal caregivers in Ontario: an epidemiological survey. Am J Public Health 1997 Dec;87(12):2002-2007. [doi: 10.2105/ajph.87.12.2002] [Medline: 9431291] 
15. Trevino KM, Prigerson HG, Maciejewski PK. Advanced cancer caregiving as a risk for major depressive episodes and generalized anxiety disorder. Psychooncology 2018 Jan;27(1):243-249 [FREE Full text] [doi: 10.1002/pon.4441] [Medline: $\underline{28426918]}$

16. Ji J, Zöller B, Sundquist K, Sundquist J. Increased risks of coronary heart disease and stroke among spousal caregivers of cancer patients. Circulation 2012 Apr 10;125(14):1742-1747. [doi: 10.1161/CIRCULATIONAHA.111.057018] [Medline: 22415143]

17. Corà A, Partinico M, Munafò M, Palomba D. Health risk factors in caregivers of terminal cancer patients: a pilot study. Cancer Nurs 2012;35(1):38-47. [doi: 10.1097/NCC.0b013e31820d0c23] [Medline: 21372699]

18. Rohleder N, Marin TJ, Ma R, Miller GE. Biologic cost of caring for a cancer patient: dysregulation of pro- and anti-inflammatory signaling pathways. J Clin Oncol 2009 Jun 20;27(18):2909-2915. [doi: 10.1200/JCO.2008.18.7435] [Medline: 19433690$]$

19. Beach SR, Schulz R, Williamson GM, Miller LS, Weiner MF, Lance CE. Risk factors for potentially harmful informal caregiver behavior. J Am Geriatr Soc 2005 Feb;53(2):255-261. [doi: 10.1111/j.1532-5415.2005.53111.x] [Medline: 15673349]

20. Beach SR, Schulz R. Family caregiver factors associated with unmet needs for care of older adults. J Am Geriatr Soc 2017 Mar;65(3):560-566. [doi: 10.1111/jgs.14547] [Medline: 27935019]

21. Lau DT, Berman R, Halpern L, Pickard AS, Schrauf R, Witt W. Exploring factors that influence informal caregiving in medication management for home hospice patients. J Palliat Med 2010 Sep;13(9):1085-1090 [FREE Full text] [doi: 10.1089/jpm.2010.0082] [Medline: 20836633]

22. Segrin C, Badger TA. Psychological and physical distress are interdependent in breast cancer survivors and their partners. Psychol Health Med 2014;19(6):716-723. [doi: 10.1080/13548506.2013.871304] [Medline: 24383980]

23. Paul C, Hall A, Oldmeadow C, Lynagh M, Campbell S, Bradstock K, et al. Dyadic interdependence of psychosocial outcomes among haematological cancer survivors and their support persons. Support Care Cancer 2017 Nov;25(11):3339-3346. [doi: 10.1007/s00520-017-3751-3] [Medline: 28550441]

24. Langer SL, Romano JM, Liu Q, Levy RL, Nielson H, Brown JD. Pain catastrophizing predicts verbal expression among children with chronic pain and their mothers. Health Psychol Open 2016 Jan;3(1):2055102916632667 [FREE Full text] [doi: 10.1177/2055102916632667] [Medline: 28070387]

25. Hodges L, Humphris G, Macfarlane G. A meta-analytic investigation of the relationship between the psychological distress of cancer patients and their carers. Soc Sci Med 2005 Jan;60(1):1-12. [doi: 10.1016/j.socscimed.2004.04.018] [Medline: 15482862]

26. Badr H, Herbert K, Bonnen MD, Asper JA, Wagner T. Dyadic Coping in Patients Undergoing Radiotherapy for Head and Neck Cancer and Their Spouses. Front Psychol 2018;9:1780 [FREE Full text] [doi: 10.3389/fpsyg.2018.01780] [Medline: 30374316]

27. Zajdel M, Helgeson V, Seltman H, Korytkowski M, Hausmann LR. Daily communal coping in couples with type 2 diabetes: links to mood and self-care. Ann Behav Med 2018 Feb 17;52(3):228-238 [FREE Full text] [doi: 10.1093/abm/kax047] [Medline: 29538665]

28. Casu G, Zaia V, Martins MD, Barbosa C, Gremigni P. A dyadic mediation study on social support, coping, and stress among couples starting fertility treatment. J Fam Psychol 2019 Apr;33(3):315-326. [doi: 10.1037/fam0000502] [Medline: $\underline{30730186]}$

29. Badr H, Carmack CL, Diefenbach MA. Psychosocial interventions for patients and caregivers in the age of new communication technologies: opportunities and challenges in cancer care. J Health Commun 2015;20(3):328-342 [FREE Full text] [doi: 10.1080/10810730.2014.965369] [Medline: 25629218]

30. Carr RM, Prestwich A, Kwasnicka D, Thøgersen-Ntoumani C, Gucciardi DF, Quested E, et al. Dyadic interventions to promote physical activity and reduce sedentary behaviour: systematic review and meta-analysis. Health Psychol Rev 2019 Mar;13(1):91-109. [doi: 10.1080/17437199.2018.1532312] [Medline: 30284501]

31. Huang L, Smith AK, Wong ML. Who will care for the caregivers? Increased needs when caring for frail older adults with cancer. J Am Geriatr Soc 2019 May;67(5):873-876. [doi: 10.1111/jgs.15863] [Medline: 30924526]

32. Shaw J, Harrison J, Young J, Butow P, Sandroussi C, Martin D, et al. Coping with newly diagnosed upper gastrointestinal cancer: a longitudinal qualitative study of family caregivers' role perception and supportive care needs. Support Care Cancer 2013 Mar;21(3):749-756. [doi: 10.1007/s00520-012-1575-8] [Medline: 22933130]

33. Waldron EA, Janke EA, Bechtel CF, Ramirez M, Cohen A. A systematic review of psychosocial interventions to improve cancer caregiver quality of life. Psychooncology 2013 Jun;22(6):1200-1207. [doi: 10.1002/pon.3118] [Medline: 22729992]

34. Applebaum AJ, Farran CJ, Marziliano AM, Pasternak AR, Breitbart W. Preliminary study of themes of meaning and psychosocial service use among informal cancer caregivers. Palliat Support Care 2014 Apr;12(2):139-148 [FREE Full text] [doi: 10.1017/S1478951513000084] [Medline: 23919966]

35. Northouse LL, Katapodi MC, Song L, Zhang L, Mood DW. Interventions with family caregivers of cancer patients: meta-analysis of randomized trials. CA Cancer J Clin 2010;60(5):317-339 [FREE Full text] [doi: 10.3322/caac.20081] [Medline: 20709946] 
36. Badr H, Herbert K, Reckson B, Rainey H, Sallam A, Gupta V. Unmet needs and relationship challenges of head and neck cancer patients and their spouses. J Psychosoc Oncol 2016;34(4):336-346 [FREE Full text] [doi: 10.1080/07347332.2016.1195901] [Medline: 27269579]

37. Ho A, Collins SR, Davis K, Doty MM. A look at working-age caregivers' roles, health concerns, and need for support. Issue Brief (Commonw Fund) $2005 \operatorname{Aug}(854): 1-12$. [Medline: 16118908]

38. Doss BD, Feinberg LK, Rothman K, Roddy MK, Comer JS. Using technology to enhance and expand interventions for couples and families: conceptual and methodological considerations. J Fam Psychol 2017 Dec;31(8):983-993 [FREE Full text] [doi: 10.1037/fam0000349] [Medline: 29309184]

39. Bhandari N, Shi Y, Jung K. Seeking health information online: does limited healthcare access matter? J Am Med Inform Assoc 2014;21(6):1113-1117 [FREE Full text] [doi: 10.1136/amiajnl-2013-002350] [Medline: 24948558]

40. Fox S, Duggan M, Purcell K. Pew Reesearch Center. 2013 Jun 20. Family Caregivers are Wired for Health URL: https:/ /www.pewresearch.org/internet/2013/06/20/family-caregivers-are-wired-for-health/ [accessed 2020-01-03]

41. Tate DF, Finkelstein EA, Khavjou O, Gustafson A. Cost effectiveness of internet interventions: review and recommendations. Ann Behav Med 2009 Aug;38(1):40-45 [FREE Full text] [doi: 10.1007/s12160-009-9131-6] [Medline: 19834778]

42. Gehring ND, McGrath P, Wozney L, Soleimani A, Bennett K, Hartling L, et al. Pediatric eMental healthcare technologies: a systematic review of implementation foci in research studies, and government and organizational documents. Implement Sci 2017 Jun 21;12(1):76 [FREE Full text] [doi: 10.1186/s13012-017-0608-6] [Medline: 28637479]

43. Bouma G, Admiraal JM, de Vries EG, Schröder CP, Walenkamp AM, Reyners AK. Internet-based support programs to alleviate psychosocial and physical symptoms in cancer patients: a literature analysis. Crit Rev Oncol Hematol 2015 Jul;95(1):26-37. [doi: 10.1016/j.critrevonc.2015.01.011] [Medline: 25701515]

44. Moradian S, Voelker N, Brown C, Liu G, Howell D. Effectiveness of internet-based interventions in managing chemotherapy-related symptoms in patients with cancer: a systematic literature review. Support Care Cancer 2018 Feb;26(2):361-374. [doi: 10.1007/s00520-017-3900-8] [Medline: 28948360]

45. Kang HS, Kim H, Park SM, Kim J. Online-based interventions for sexual health among individuals with cancer: a systematic review. BMC Health Serv Res 2018 Mar 7;18(1):167 [FREE Full text] [doi: 10.1186/s12913-018-2972-6] [Medline: 29514669]

46. Arem H, Irwin M. A review of web-based weight loss interventions in adults. Obes Rev 2011 May;12(5):e236-e243 [FREE Full text] [doi: 10.1111/j.1467-789X.2010.00787.x] [Medline: 20804523]

47. Morrison D, Wyke S, Agur K, Cameron EJ, Docking RI, Mackenzie AM, et al. Digital asthma self-management interventions: a systematic review. J Med Internet Res 2014 Feb 18;16(2):e51 [FREE Full text] [doi: 10.2196/jmir.2814] [Medline: 24550161]

48. Widmer RJ, Collins NM, Collins CS, West CP, Lerman LO, Lerman A. Digital health interventions for the prevention of cardiovascular disease: a systematic review and meta-analysis. Mayo Clin Proc 2015 Apr;90(4):469-480 [FREE Full text] [doi: 10.1016/j.mayocp.2014.12.026] [Medline: 25841251]

49. Guse K, Levine D, Martins S, Lira A, Gaarde J, Westmorland W, et al. Interventions using new digital media to improve adolescent sexual health: a systematic review. J Adolesc Health 2012 Dec;51(6):535-543. [doi: 10.1016/j.jadohealth.2012.03.014] [Medline: 23174462]

50. Hollis C, Falconer CJ, Martin JL, Whittington C, Stockton S, Glazebrook C, et al. Annual Research Review: Digital health interventions for children and young people with mental health problems - a systematic and meta-review. J Child Psychol Psychiatry 2017 Apr;58(4):474-503. [doi: 10.1111/jcpp.12663] [Medline: 27943285]

51. Li J, Theng Y, Foo S. Game-based digital interventions for depression therapy: a systematic review and meta-analysis. Cyberpsychol Behav Soc Netw 2014 Aug;17(8):519-527 [FREE Full text] [doi: 10.1089/cyber.2013.0481] [Medline: 24810933]

52. Grist R, Porter J, Stallard P. Mental health mobile apps for preadolescents and adolescents: a systematic review. J Med Internet Res 2017 May 25;19(5):e176 [FREE Full text] [doi: 10.2196/jmir.7332] [Medline: 28546138]

53. Neve M, Morgan P, Jones P, Collins C. Effectiveness of web-based interventions in achieving weight loss and weight loss maintenance in overweight and obese adults: a systematic review with meta-analysis. Obes Rev 2010 Apr;11(4):306-321. [doi: 10.1111/j.1467-789X.2009.00646.x] [Medline: 19754633]

54. Hutchesson MJ, Rollo ME, Krukowski R, Ells L, Harvey J, Morgan PJ, et al. eHealth interventions for the prevention and treatment of overweight and obesity in adults: a systematic review with meta-analysis. Obes Rev 2015 May;16(5):376-392. [doi: 10.1111/obr.12268] [Medline: 25753009]

55. Bennett GG, Steinberg DM, Stoute C, Lanpher M, Lane I, Askew S, et al. Electronic health (eHealth) interventions for weight management among racial/ethnic minority adults: a systematic review. Obes Rev 2014 Oct;15(Suppl 4):146-158. [doi: 10.1111/obr.12218] [Medline: 25196411]

56. Sin J, Henderson C, Spain D, Cornelius V, Chen T, Gillard S. eHealth interventions for family carers of people with long term illness: a promising approach? Clin Psychol Rev 2018 Mar;60:109-125 [FREE Full text] [doi: 10.1016/j.cpr.2018.01.008] [Medline: 29429856] 
57. Wozney L, de Souza LM, Kervin E, Queluz F, McGrath PJ, Keefe J. Commercially available mobile apps for caregivers of people with Alzheimer disease or other related dementias: systematic search. JMIR Aging 2018 Dec 7;1(2):e12274 [FREE Full text] [doi: 10.2196/12274] [Medline: $\underline{\text { 31518255] }}$

58. Ploeg J, Ali MU, Markle-Reid M, Valaitis R, Bartholomew A, Fitzpatrick-Lewis D, et al. Caregiver-focused, web-based interventions: systematic review and meta-analysis (part 2). J Med Internet Res 2018 Oct 26;20(10):e11247 [FREE Full text] [doi: 10.2196/11247] [Medline: $\underline{30368439}$ ]

59. Hopwood J, Walker N, McDonagh L, Rait G, Walters K, Iliffe S, et al. Internet-based interventions aimed at supporting family caregivers of people with dementia: systematic review. J Med Internet Res 2018 Jun 12;20(6):e216 [FREE Full text] [doi: 10.2196/jmir.9548] [Medline: 29895512]

60. Egan KJ, Pinto-Bruno ÁC, Bighelli I, Berg-Weger M, van Straten A, Albanese E, et al. Online training and support programs designed to improve mental health and reduce burden among caregivers of people with dementia: a systematic review. J Am Med Dir Assoc 2018 Mar;19(3):200-6.e1. [doi: 10.1016/j.jamda.2017.10.023] [Medline: 29306605]

61. Kaltenbaugh D, Klem ML, Hu L, Turi E, Haines A, Lingler JH. Using web-based interventions to support caregivers of patients with cancer: a systematic review. Oncol Nurs Forum 2015 Mar;42(2):156-164. [doi: 10.1188/15.0NF.156-164] [Medline: 25806882]

62. US Department of Veterans Affairs, Health Services Research \& Development Service. Mobile Applications and Internet-Based Approaches for Supporting Non-Professional Caregivers: A Systematic Review. Scotts Valley, California , US: Createspace Independent Pub; 2012.

63. Hu C, Kung S, Rummans TA, Clark MM, Lapid MI. Reducing caregiver stress with internet-based interventions: a systematic review of open-label and randomized controlled trials. J Am Med Inform Assoc 2015 Apr;22(e1):e194-e209. [doi: 10.1136/amiajnl-2014-002817] [Medline: 25125686]

64. Wasilewski MB, Stinson JN, Cameron JI. Web-based health interventions for family caregivers of elderly individuals: a Scoping Review. Int J Med Inform 2017 Jul;103:109-138. [doi: 10.1016/j.ijmedinf.2017.04.009] [Medline: 28550996]

65. Powell J, Chiu T, Eysenbach G. A systematic review of networked technologies supporting carers of people with dementia. J Telemed Telecare 2008;14(3):154-156. [doi: 10.1258/jtt.2008.003018] [Medline: 18430288]

66. Godwin KM, Mills WL, Anderson JA, Kunik ME. Technology-driven interventions for caregivers of persons with dementia: a systematic review. Am J Alzheimers Dis Other Demen 2013 May;28(3):216-222. [doi: 10.1177/1533317513481091] [Medline: 23528881]

67. McKechnie V, Barker C, Stott J. Effectiveness of computer-mediated interventions for informal carers of people with dementia-a systematic review. Int Psychogeriatr 2014 Oct;26(10):1619-1637 [FREE Full text] [doi: 10.1017/S1041610214001045] [Medline: 24989249]

68. Boots LM, de Vugt ME, van Knippenberg RJ, Kempen GI, Verhey FR. A systematic review of internet-based supportive interventions for caregivers of patients with dementia. Int J Geriatr Psychiatry 2014 Apr;29(4):331-344. [doi: 10.1002/gps.4016] [Medline: 23963684]

69. Peters MD, Godfrey CM, Khalil H, McInerney P, Parker D, Soares CB. Guidance for conducting systematic scoping reviews. Int J Evid Based Healthc 2015 Sep;13(3):141-146. [doi: 10.1097/XEB.0000000000000050] [Medline: 26134548]

70. Tricco AC, Lillie E, Zarin W, O'Brien K, Colquhoun H, Kastner M, et al. A scoping review on the conduct and reporting of scoping reviews. BMC Med Res Methodol 2016 Feb 9;16:15 [FREE Full text] [doi: 10.1186/s12874-016-0116-4] [Medline: 26857112]

71. NHS Centre for Reviews and Dissemination. The University of York. Undertaking Systematic Reviews of Research on Effectiveness: CRD's Guidance for Those Carrying Out or Commissioning Reviews URL: https://www.crd.york.ac.uk/ CRDWeb/ShowRecord.asp?AccessionNumber=32001000984\&AccessionNumber=32001000984 [accessed 2020-01-03]

72. Eng TR. The Ehealth Landscape: A Terrain Map of Emerging Information and Communication Technologies in Health and Health Care. Princeton, NJ, USA: Robert Wood Johnson Foundation; 2001.

73. Eysenbach G. What is e-health? J Med Internet Res 2001;3(2):E20 [FREE Full text] [doi: 10.2196/jmir.3.2.e20] [Medline: 11720962]

74. Ritterband LM, Thorndike FP, Cox DJ, Kovatchev BP, Gonder-Frederick LA. A behavior change model for internet interventions. Ann Behav Med 2009 Aug;38(1):18-27 [FREE Full text] [doi: 10.1007/s12160-009-9133-4] [Medline: 19802647]

75. Veritas Health Innovation. Covidence Systematic Review Software. Melbourne, Australia URL: https://www.covidence. org [accessed 2020-01-03]

76. Moher D, Liberati A, Tetzlaff J, Altman DG, PRISMA Group. Preferred reporting items for systematic reviews and meta-analyses: the PRISMA statement. Br Med J 2009 Jul 21;339:b2535 [FREE Full text] [doi: 10.1136/bmj.b2535] [Medline: 19622551]

77. Ritterband LM, Cox DJ, Walker LS, Kovatchev B, McKnight L, Patel K, et al. An internet intervention as adjunctive therapy for pediatric encopresis. J Consult Clin Psychol 2003 Oct;71(5):910-917. [doi: 10.1037/0022-006X.71.5.910] [Medline: $\underline{14516239]}$

78. Baranowski T, Baranowski JC, Cullen KW, Thompson DI, Nicklas T, Zakeri IE, et al. The Fun, Food, and Fitness Project (FFFP): the Baylor GEMS pilot study. Ethn Dis 2003;13(1 Suppl 1):S30-S39. [Medline: 12713209] 
79. Anderson RE, Spence SH, Donovan CL, March S, Prosser S, Kenardy J. Working alliance in online cognitive behavior therapy for anxiety disorders in youth: comparison with clinic delivery and its role in predicting outcome. J Med Internet Res 2012 Jun 28;14(3):e88 [FREE Full text] [doi: 10.2196/jmir.1848] [Medline: 22789657]

80. van Voorhees BW, Gladstone T, Cordel S, Marko-Holguin M, Beardslee W, Kuwabara S, et al. Development of a technology-based behavioral vaccine to prevent adolescent depression: A health system integration model. Internet Interv 2015 Sep;2(3):303-313 [FREE Full text] [doi: 10.1016/j.invent.2015.07.004] [Medline: 30473992]

81. Gladstone TR, Terrizzi DA, Stinson A, Nidetz J, Canel J, Ching E, et al. Effect of internet-based cognitive behavioral humanistic and interpersonal training vs internet-based general health education on adolescent depression in primary care: a randomized clinical trial. JAMA Netw Open 2018 Nov;1(7):pii: e184278 [FREE Full text] [doi: 10.1001/jamanetworkopen.2018.4278] [Medline: 30533601]

82. Conaughton RJ, Donovan CL, March S. Efficacy of an internet-based CBT program for children with comorbid High Functioning Autism Spectrum Disorder and anxiety: a randomised controlled trial. J Affect Disord 2017 Aug 15;218:260-268. [doi: 10.1016/j.jad.2017.04.032] [Medline: 28477505]

83. Lee R, Leung C, Chen H, Louie L, Brown M, Chen J, et al. The impact of a school-based weight management program involving parents via mHealth for overweight and obese children and adolescents with intellectual disability: a randomized controlled trial. Int J Environ Res Public Health 2017 Oct 5;14(10):pii: E1178 [FREE Full text] [doi: 10.3390/ijerph14101178] [Medline: 28981460]

84. Palermo TM, Dudeney J, Santanelli JP, Carletti A, Zempsky WT. Feasibility and acceptability of internet-delivered cognitive behavioral therapy for chronic pain in adolescents with sickle cell disease and their parents. J Pediatr Hematol Oncol 2018 Mar;40(2):122-127 [FREE Full text] [doi: 10.1097/MPH.0000000000001018] [Medline: 29176462]

85. Holland JE, DeMaso DR, Rosoklija I, Johnson KL, Manning D, Bellows AL, et al. Self-cathing experience journal: enhancing the patient and family experience in clean intermittent catheterization. J Pediatr Urol 2015 Aug;11(4):187.e1-187.e6. [doi: 10.1016/j.jpurol.2015.03.011] [Medline: 26028181]

86. Aikens JE, Zivin K, Trivedi R, Piette JD. Diabetes self-management support using mHealth and enhanced informal caregiving. J Diabetes Complications 2014;28(2):171-176 [FREE Full text] [doi: 10.1016/j.jdiacomp.2013.11.008] [Medline: 24374137]

87. Aikens JE, Rosland A, Piette JD. Improvements in illness self-management and psychological distress associated with telemonitoring support for adults with diabetes. Prim Care Diabetes 2015 Apr;9(2):127-134 [FREE Full text] [doi: 10.1016/j.pcd.2014.06.003] [Medline: 25065270]

88. Aikens JE, Trivedi R, Heapy A, Pfeiffer PN, Piette JD. Potential impact of incorporating a patient-selected support person into mHealth for depression. J Gen Intern Med 2015 Jun;30(6):797-803 [FREE Full text] [doi: 10.1007/s11606-015-3208-7] [Medline: 25666218]

89. Aikens JE, Trivedi R, Aron DC, Piette JD. Integrating support persons into diabetes telemonitoring to improve self-management and medication adherence. J Gen Intern Med 2015 Mar;30(3):319-326 [FREE Full text] [doi: 10.1007/s11606-014-3101-9] [Medline: 25421436]

90. Piette JD, Striplin D, Marinec N, Chen J, Aikens JE. A randomized trial of mobile health support for heart failure patients and their informal caregivers: impacts on caregiver-reported outcomes. Med Care 2015 Aug;53(8):692-699 [FREE Full text] [doi: 10.1097/MLR.0000000000000378] [Medline: 26125415]

91. Schover LR, Canada AL, Yuan Y, Sui D, Neese L, Jenkins R, et al. A randomized trial of internet-based versus traditional sexual counseling for couples after localized prostate cancer treatment. Cancer 2012 Jan 15;118(2):500-509 [FREE Full text] [doi: 10.1002/cncr.26308] [Medline: 21953578]

92. Hummel SB, van Lankveld JJ, Oldenburg HS, Hahn DE, Kieffer JM, Gerritsma MA, et al. Efficacy of internet-based cognitive behavioral therapy in improving sexual functioning of breast cancer survivors: results of a randomized controlled trial. J Clin Oncol 2017 Apr 20;35(12):1328-1340. [doi: 10.1200/JCO.2016.69.6021] [Medline: 28240966]

93. Hummel SB, van Lankveld JJ, Oldenburg HS, Hahn DE, Kieffer JM, Gerritsma MA, et al. Sexual functioning and relationship satisfaction of partners of breast cancer survivors who receive internet-based sex therapy. J Sex Marital Ther 2019;45(2):91-102. [doi: 10.1080/0092623X.2018.1488325] [Medline: 30040589]

94. Jolstedt M, Wahlund T, Lenhard F, Ljótsson B, Mataix-Cols D, Nord M, et al. Efficacy and cost-effectiveness of therapist-guided internet cognitive behavioural therapy for paediatric anxiety disorders: a single-centre, single-blind, randomised controlled trial. Lancet Child Adolesc Health 2018;2(11):792-801. [doi: 10.1016/s2352-4642(18)30275-x]

95. Ellis DA, Carcone AI, Ondersma SJ, Naar-King S, Dekelbab B, Moltz K. Brief computer-delivered intervention to increase parental monitoring in families of African American adolescents with type 1 diabetes: a randomized controlled trial. Telemed J E Health 2017 Jun;23(6):493-502 [FREE Full text] [doi: 10.1089/tmj.2016.0182] [Medline: 28061319]

96. Kazak A, Simms S, Rourke MT. Family systems practice in pediatric psychology. J Pediatr Psychol 2002 Mar;27(2):133-143. [doi: 10.1093/jpepsy/27.2.133] [Medline: 11821497]

97. Harrison TM. Family-centered pediatric nursing care: state of the science. J Pediatr Nurs 2010 Oct;25(5):335-343 [FREE Full text] [doi: 10.1016/j.pedn.2009.01.006] [Medline: 20816555]

98. Kuo DZ, Houtrow AJ, Arango P, Kuhlthau KA, Simmons JM, Neff JM. Family-centered care: current applications and future directions in pediatric health care. Matern Child Health J 2012 Feb;16(2):297-305 [FREE Full text] [doi: 10.1007/s10995-011-0751-7] [Medline: 21318293] 
99. World Health Organization. National Cancer Control Programmes: Policies and Managerial Guidelines. Second Edition. Geneva: World Health Organization; 2002.

100. Davidson JE, Powers K, Hedayat KM, Tieszen M, Kon AA, Shepard E, American College of Critical Care Medicine Task Force 2004-2005, Society of Critical Care Medicine. Clinical practice guidelines for support of the family in the patient-centered intensive care unit: American College of Critical Care Medicine Task Force 2004-2005. Crit Care Med 2007 Feb;35(2):605-622. [doi: 10.1097/01.CCM.0000254067.14607.EB] [Medline: 17205007]

101. Morrison RS, Meier DE. Clinical practice. Palliative care. N Engl J Med 2004 Jun 17;350(25):2582-2590. [doi: 10.1056/NEJMcp035232] [Medline: 15201415$]$

102. AARP, Project Catalyst. AARP Public Policy. 2016 Apr. Caregivers \& Technology: What they Want and Need URL: https://www.aarp.org/content/dam/aarp/research/surveys_statistics/ltc/2018/caregivers-technology-needs.doi.10.26419-2Fres. 00191.002.pdf [accessed 2020-01-03]

103. Shaffer KM, Chow PI, Cohn WF, Ingersoll KS, Ritterband LM. Informal caregivers' use of internet-based health resources: an analysis of the health information national trends survey. JMIR Aging 2018 Dec 18;1(2):e11051 [FREE Full text] [doi: 10.2196/11051] [Medline: 31518244$]$

104. Lapid MI, Atherton PJ, Clark MM, Kung S, Sloan JA, Rummans TA. Cancer caregiver: perceived benefits of technology. Telemed J E Health 2015 Nov;21(11):893-902 [FREE Full text] [doi: 10.1089/tmj.2014.0117] [Medline: 26075800]

105. Bolle S, Romijn G, Smets EM, Loos EF, Kunneman M, van Weert JC. Older cancer patients' user experiences with web-based health information tools: a think-aloud study. J Med Internet Res 2016 Jul 25;18(7):e208 [FREE Full text] [doi: 10.2196/jmir.5618] [Medline: 27457709]

106. Barak A, Klein B, Proudfoot JG. Defining internet-supported therapeutic interventions. Ann Behav Med 2009 Aug;38(1):4-17. [doi: 10.1007/s12160-009-9130-7] [Medline: 19787305]

107. Aardoom JJ, Dingemans AE, Spinhoven P, van Ginkel JR, de Rooij M, van Furth EF. Web-based fully automated self-help with different levels of therapist support for individuals with eating disorder symptoms: a randomized controlled trial. $\mathbf{J}$

Med Internet Res 2016 Jun 17;18(6):e159 [FREE Full text] [doi: 10.2196/jmir.5709] [Medline: 27317358]

108. Roddy MK, Nowlan KM, Doss BD. A randomized controlled trial of coach contact during a brief online intervention for distressed couples. Fam Process 2017 Dec;56(4):835-851. [doi: 10.1111/famp.12262] [Medline: 27859100]

109. Dennison L, Morrison L, Lloyd S, Phillips D, Stuart B, Williams S, et al. Does brief telephone support improve engagement with a web-based weight management intervention? Randomized controlled trial. J Med Internet Res 2014 Mar 28;16(3):e95 [FREE Full text] [doi: 10.2196/jmir.3199] [Medline: 24681761]

110. Patrick K, Hekler EB, Estrin D, Mohr DC, Riper H, Crane D, et al. The pace of technologic change: implications for digital health behavior intervention research. Am J Prev Med 2016 Nov;51(5):816-824. [doi: 10.1016/j.amepre.2016.05.001] [Medline: 27745681]

111. Northouse L, Schafenacker A, Barr KL, Katapodi M, Yoon H, Brittain K, et al. A tailored web-based psychoeducational intervention for cancer patients and their family caregivers. Cancer Nurs 2014;37(5):321-330 [FREE Full text] [doi: 10.1097/NCC.0000000000000159] [Medline: 24945270]

112. Berg CA, Upchurch R. A developmental-contextual model of couples coping with chronic illness across the adult life span. Psychol Bull 2007 Nov;133(6):920-954. [doi: 10.1037/0033-2909.133.6.920] [Medline: 17967089]

113. Revenson TA, Kayser K, Bodenmann G, editors. Couples Coping With Stress: Emerging Perspectives On Dyadic Coping. Washington, DC, US: American Psychological Association; 2005.

114. Bodenmann G. Dyadic coping and its significance for marital functioning. In: Revenson TA, Kayser K, Bodenmann G, editors. Couples Coping with Stress: Emerging Perspectives on Dyadic Coping. Washington, DC, US: American Psychological Association; 2005:33-49.

115. Rotondi AJ, Anderson CM, Haas GL, Eack SM, Spring MB, Ganguli R, et al. Web-based psychoeducational intervention for persons with schizophrenia and their supporters: one-year outcomes. Psychiatr Serv 2010 Nov;61(11):1099-1105. [doi: 10.1176/ps.2010.61.11.1099] [Medline: 21041348]

116. Rotondi AJ, Haas GL, Anderson CM, Newhill CE, Spring MB, Ganguli R, et al. A clinical trial to test the feasibility of a telehealth psychoeducational intervention for persons with schizophrenia and their families: intervention and 3-month findings. Rehabil Psychol 2005 Nov;50(4):325-336 [FREE Full text] [doi: 10.1037/0090-5550.50.4.325] [Medline: 26321774]

117. Rotondi A, Haas G, Anderson C, Mueser K. Effectiveness of web-based multi-family treatment delivered to the homes of persons with schizophrenia and their supporters. Schizophr Bull 2013;39(suppl 1):S350.

118. Hannon TS, Yazel-Smith LG, Hatton AS, Stanton JL, Moser EA, Li X, et al. Advancing diabetes management in adolescents: comparative effectiveness of mobile self-monitoring blood glucose technology and family-centered goal setting. Pediatr Diabetes 2018 Jun;19(4):776-781 [FREE Full text] [doi: 10.1111/pedi.12648] [Medline: 29504207]

119. Quirk H, Glazebrook C, Blake H. A physical activity intervention for children with type 1 diabetes- steps to active kids with diabetes (STAK-D): a feasibility study. BMC Pediatr 2018 Feb 7;18(1):37 [FREE Full text] [doi: 10.1186/s12887-018-1036-8] [Medline: 29415687]

120. McCormick M, Reed-Knight B, Lewis JD, Gold BD, Blount RL. Coping skills for reducing pain and somatic symptoms in adolescents with IBD. Inflamm Bowel Dis 2010 Dec;16(12):2148-2157. [doi: 10.1002/ibd.21302] [Medline: 20848505] 
121. Reed-Knight B, McCormick M, Lewis JD, Blount RL. Participation and attrition in a coping skills intervention for adolescent girls with inflammatory bowel disease. J Clin Psychol Med Settings 2012 Jun;19(2):188-196. [doi: 10.1007/s10880-011-9269-9] [Medline: 22076655]

122. Bonnert M, Ljótsson B, Hedman E, Serlachius E, Simren M, Benninga MA, et al. Internet-delivered cognitive behavior therapy for adolescents with functional gastrointestinal disorders: a pilot study. Gastroenterology 2014;146(5):S-897. [doi: 10.1016/s0016-5085(14)63260-1]

123. Bonnert M, Olén O, Lalouni M, Benninga MA, Bottai M, Engelbrektsson J, et al. Internet-delivered cognitive behavior therapy for adolescents with irritable bowel syndrome: a randomized controlled trial. Am J Gastroenterol 2017 Jan;112(1):152-162. [doi: 10.1038/ajg.2016.503] [Medline: 27845338]

124. Bonnert M, Olén O, Bjureberg J, Lalouni M, Hedman-Lagerlöf E, Serlachius E, et al. The role of avoidance behavior in the treatment of adolescents with irritable bowel syndrome: a mediation analysis. Behav Res Ther 2018 Jun;105:27-35 [FREE Full text] [doi: 10.1016/j.brat.2018.03.006] [Medline: 29614378]

125. Sampaio F, Bonnert M, Olén O, Hedman E, Lalouni M, Lenhard F, et al. Cost-effectiveness of internet-delivered cognitive-behavioural therapy for adolescents with irritable bowel syndrome. BMJ Open 2019 Jan 24;9(1):e023881 [FREE Full text] [doi: 10.1136/bmjopen-2018-023881] [Medline: 30679293]

126. Bonnert M, Olén O, Lalouni M, Hedman-Lagerlöf E, Särnholm J, Serlachius E, et al. Internet-delivered exposure-based cognitive-behavioral therapy for adolescents with functional abdominal pain or functional dyspepsia: a feasibility study. Behav Ther 2019 Jan;50(1):177-188 [FREE Full text] [doi: 10.1016/j.beth.2018.05.002] [Medline: $\underline{30661558]}$

127. Lalouni M, Ljótsson B, Bonnert M, Hedman-Lagerlöf E, Högström J, Serlachius E, et al. Internet-delivered cognitive behavioral therapy for children with pain-related functional gastrointestinal disorders: feasibility study. JMIR Ment Health 2017 Aug 10;4(3):e32 [FREE Full text] [doi: 10.2196/mental.7985] [Medline: 28798012]

128. Lalouni M, Ljótsson B, Bonnert M, Ssegonja R, Benninga M, Bjureberg J, et al. Clinical and cost effectiveness of online cognitive behavioral therapy in children with functional abdominal pain disorders. Clin Gastroenterol Hepatol 2019 Oct;17(11):2236-44.e11 [FREE Full text] [doi: 10.1016/j.cgh.2018.11.043] [Medline: $\underline{30502501]}$

129. Ritterband LM, Ardalan K, Thorndike FP, Magee JC, Saylor DK, Cox DJ, et al. Real world use of an internet intervention for pediatric encopresis. J Med Internet Res 2008 Jun 30;10(2):e16 [FREE Full text] [doi: 10.2196/jmir.1081] [Medline: $\underline{18653440]}$

130. Ritterband LM, Thorndike FP, Lord HR, Borowitz SM, Walker LS, Ingersoll KS, et al. An RCT of an internet intervention for pediatric encopresis with one year follow-up. Clin Pract Pediatr Psychol 2013 Mar;1(1):68-80 [FREE Full text] [doi: 10.1037/cpp0000007] [Medline: 24040581]

131. Lenhard F, Vigerland S, Andersson E, Rück C, Mataix-Cols D, Thulin U, et al. Internet-delivered cognitive behavior therapy for adolescents with obsessive-compulsive disorder: an open trial. PLoS One 2014;9(6):e100773 [FREE Full text] [doi: 10.1371/journal.pone.0100773] [Medline: 24949622]

132. Lenhard F, Vigerland S, Engberg H, Hallberg A, Thermaenius H, Serlachius E. 'On My Own, but Not Alone' - adolescents' experiences of internet-delivered cognitive behavior therapy for obsessive-compulsive disorder. PLoS One 2016;11(10):e0164311 [FREE Full text] [doi: 10.1371/journal.pone.0164311] [Medline: 27711249]

133. Lenhard F, Ssegonja R, Andersson E, Feldman I, Rück C, Mataix-Cols D, et al. Cost-effectiveness of therapist-guided internet-delivered cognitive behaviour therapy for paediatric obsessive-compulsive disorder: results from a randomised controlled trial. BMJ Open 2017 May 17;7(5):e015246 [FREE Full text] [doi: 10.1136/bmjopen-2016-015246] [Medline: 28515196]

134. Lenhard F, Andersson E, Mataix-Cols D, Rück C, Vigerland S, Högström J, et al. Therapist-guided, internet-delivered cognitive-behavioral therapy for adolescents with obsessive-compulsive disorder: a randomized controlled trial. J Am Acad Child Adolesc Psychiatry 2017 Jan;56(1):10-9.e2 [FREE Full text] [doi: 10.1016/j.jaac.2016.09.515] [Medline: 27993223]

135. Aspvall K, Andrén P, Lenhard F, Andersson E, Mataix-Cols D, Serlachius E. Internet-delivered cognitive behavioural therapy for young children with obsessive-compulsive disorder: development and initial evaluation of the BIP OCD Junior programme. BJPsych Open 2018 May;4(3):106-112 [FREE Full text] [doi: 10.1192/bjo.2018.10] [Medline: 29971153]

136. Nordh M, Vigerland S, Öst LG, Ljótsson B, Mataix-Cols D, Serlachius E, et al. Therapist-guided internet-delivered cognitive-behavioural therapy supplemented with group exposure sessions for adolescents with social anxiety disorder: a feasibility trial. BMJ Open 2017 Dec 14;7(12):e018345 [FREE Full text] [doi: 10.1136/bmjopen-2017-018345] [Medline: 29247101]

137. Andrén P, Aspvall K, de la Cruz LF, Wiktor P, Romano S, Andersson E, et al. Therapist-guided and parent-guided internet-delivered behaviour therapy for paediatric Tourette's disorder: a pilot randomised controlled trial with long-term follow-up. BMJ Open 2019 Feb 15;9(2):e024685 [FREE Full text] [doi: 10.1136/bmjopen-2018-024685] [Medline: 30772854]

138. Spence SH, Holmes JM, March S, Lipp OV. The feasibility and outcome of clinic plus internet delivery of cognitive-behavior therapy for childhood anxiety. J Consult Clin Psychol 2006 Jun;74(3):614-621. [doi: 10.1037/0022-006X.74.3.614] [Medline: 16822117]

139. March S, Spence SH, Donovan CL. The efficacy of an internet-based cognitive-behavioral therapy intervention for child anxiety disorders. J Pediatr Psychol 2009 Jun;34(5):474-487. [doi: 10.1093/jpepsy/jsn099] [Medline: 18794187] 
140. Spence SH, Donovan CL, March S, Gamble A, Anderson RE, Prosser S, et al. A randomized controlled trial of online versus clinic-based CBT for adolescent anxiety. J Consult Clin Psychol 2011 Oct;79(5):629-642. [doi: 10.1037/a0024512] [Medline: 21744945]

141. Stasiak K, Merry SN, Frampton C, Moor S. Delivering solid treatments on shaky ground: Feasibility study of an online therapy for child anxiety in the aftermath of a natural disaster. Psychother Res 2018 Jul;28(4):643-653. [doi: 10.1080/10503307.2016.1244617] [Medline: 27781568]

142. Keller ML. ProQuest Search.: ProQuest Dissertations Publishing; 2010. An Internet Cognitive-Behavioral Skills-Based Program for Child Anxiety URL: https://search.proquest.com/docview/304853705 [accessed 2020-01-03]

143. Vigerland S, Ljótsson B, Thulin U, Öst LG, Andersson G, Serlachius E. Internet-delivered cognitive behavioural therapy for children with anxiety disorders: a randomised controlled trial. Behav Res Ther 2016 Jan;76:47-56 [FREE Full text] [doi: 10.1016/j.brat.2015.11.006] [Medline: 26649465]

144. Rees CS, Anderson RA, Kane RT, Finlay-Jones AL. Online obsessive-compulsive disorder treatment: preliminary results of the 'OCD? Not me!' self-guided internet-based cognitive behavioral therapy program for young people. JMIR Ment Health 2016 Jul 5;3(3):e29 [FREE Full text] [doi: 10.2196/mental.5363] [Medline: 27381977]

145. Carpenter EM, Frankel F, Marina M, Duan N, Smalley SL. Internet treatment delivery of parent-adolescent conflict training for families with an ADHD teen: a feasibility study. Child Fam Behav Ther 2004;26(3):1-20. [doi: 10.1300/j019v26n03_01]

146. Wilson DK, Sweeney AM, Law LH, Kitzman-Ulrich H, Resnicow K. Web-based program exposure and retention in the families improving together for weight loss trial. Ann Behav Med 2019 Mar 20;53(4):399-404 [FREE Full text] [doi: 10.1093/abm/kay047] [Medline: 30892641]

147. Tripicchio GL, Ammerman AS, Neshteruk C, Faith MS, Dean K, Befort C, et al. Technology components as adjuncts to family-based pediatric obesity treatment in low-income minority youth. Child Obes 2017 Dec;13(6):433-442 [FREE Full text] [doi: 10.1089/chi.2017.0021] [Medline: 28727927]

148. Büchter D, Kowatsch T, Brogle B, Dintheer-ter-Velde A, Wiegand D, Pletikosa I, et al. Home support of obese children and adolescents by means of health information technology system: a pilot study for a psychosomatic therapy concept. Swiss Med Weekly 2014;144(suppl 203):17 [FREE Full text]

149. Kowatsch T, Maass W, Pletikosa CI, Xu R. Design of a Health Information System Enhancing the Performance of Obesity Expert and Children Teams. In: Proceedings of the 2014 European Conference on Information Systems. 2014 Presented at: ECIS'14; June 9-11, 2014; Tel Aviv, Israel.

150. Xu R, Cvijikj I, Kowatsch T, Michahelles F. Tell Me What to Eat - Design and Evaluation of a Mobile Companion Helping Children and Their Parents to Plan Nutrition Intake. In: Proceedings of the 2014 European Conference on Ambient Intelligence. 2014 Presented at: AmI'14; November 11-13, 2014; Eindhoven, Netherlands. [doi: 10.1007/978-3-319-14112-19]

151. White MA, Martin PD, Newton RL, Walden HM, York-Crowe EE, Gordon ST, et al. Mediators of weight loss in a family-based intervention presented over the internet. Obes Res 2004 Jul;12(7):1050-1059 [FREE Full text] [doi: 10.1038/oby.2004.132] [Medline: 15292468]

152. Williamson DA, Martin PD, White MA, Newton R, Walden H, York-Crowe E, et al. Efficacy of an internet-based behavioral weight loss program for overweight adolescent African-American girls. Eat Weight Disord 2005 Sep;10(3):193-203. [doi:

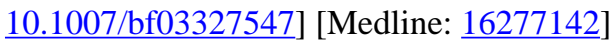

153. Williamson DA, Walden HM, White MA, York-Crowe E, Newton RL, Alfonso A, et al. Two-year internet-based randomized controlled trial for weight loss in African-American girls. Obesity (Silver Spring) 2006 Jul;14(7):1231-1243 [FREE Full text] [doi: 10.1038/oby.2006.140] [Medline: 16899804]

154. Moore BA, O'Donohue WT. Evaluating a web-based cognitive behavioral intervention for the prevention and treatment of pediatric obesity. In: O'Donohue WT, Draper C, editors. Stepped Care and e-Health. New York, NY, US: Springer; 2011:137-149.

155. Mâsse LC, Watts AW, Barr SI, Tu AW, Panagiotopoulos C, Geller J, et al. Individual and household predictors of adolescents' adherence to a web-based intervention. Ann Behav Med 2015 Jun;49(3):371-383. [doi: 10.1007/s12160-014-9658-z] [Medline: 25270826]

156. Tu AW, Watts AW, Chanoine J, Panagiotopoulos C, Geller J, Brant R, et al. Does parental and adolescent participation in an e-health lifestyle modification intervention improves weight outcomes? BMC Public Health 2017 Apr 24;17(1):352 [FREE Full text] [doi: 10.1186/s12889-017-4220-0] [Medline: 28438202]

157. Nieto R, Hernández E, Boixadós M, Huguet A, Beneitez I, McGrath P. Testing the feasibility of DARWeb: an online intervention for children with functional abdominal pain and their parents. Clin J Pain 2015 Jun;31(6):493-503. [doi: 10.1097/AJP.0000000000000199] [Medline: 25551478]

158. Voerman JS, Remerie S, Westendorp T, Timman R, Busschbach JJ, Passchier J, et al. Effects of a guided internet-delivered self-help intervention for adolescents with chronic pain. J Pain 2015 Nov;16(11):1115-1126. [doi: 10.1016/j.jpain.2015.07.011] [Medline: 26281947]

159. Palermo TM, Wilson AC, Peters M, Lewandowski A, Somhegyi H. Randomized controlled trial of an Internet-delivered family cognitive-behavioral therapy intervention for children and adolescents with chronic pain. Pain 2009 Nov;146(1-2):205-213 [FREE Full text] [doi: 10.1016/j.pain.2009.07.034] [Medline: 19695776] 
160. Long AC, Palermo TM. Brief report: web-based management of adolescent chronic pain: development and usability testing of an online family cognitive behavioral therapy program. J Pediatr Psychol 2009 Jun;34(5):511-516 [FREE Full text] [doi: 10.1093/jpepsy/jsn082] [Medline: $\underline{18669578]}$

161. Fales J, Palermo TM, Law EF, Wilson AC. Sleep outcomes in youth with chronic pain participating in a randomized controlled trial of online cognitive-behavioral therapy for pain management. Behav Sleep Med 2015;13(2):107-123 [FREE Full text] [doi: 10.1080/15402002.2013.845779] [Medline: 24484373]

162. Law EF, Beals-Erickson SE, Noel M, Claar R, Palermo TM. Pilot randomized controlled trial of internet-delivered cognitive-behavioral treatment for pediatric headache. Headache 2015;55(10):1410-1425 [FREE Full text] [doi: 10.1111/head.12635] [Medline: 26316194]

163. Palermo TM, Law EF, Zhou C, Holley AL, Logan D, Tai G. Trajectories of change during a randomized controlled trial of internet-delivered psychological treatment for adolescent chronic pain: how does change in pain and function relate? Pain 2015 Apr;156(4):626-634 [FREE Full text] [doi: 10.1097/01.j.pain.0000460355.17246.6c] [Medline: 25775441]

164. Palermo TM, Law EF, Fales J, Bromberg MH, Jessen-Fiddick T, Tai G. Internet-delivered cognitive-behavioral treatment for adolescents with chronic pain and their parents: a randomized controlled multicenter trial. Pain 2016 Jan;157(1):174-185 [FREE Full text] [doi: 10.1097/j.pain.0000000000000348] [Medline: 26335910]

165. Fisher E, Bromberg MH, Tai G, Palermo TM. Adolescent and parent treatment goals in an internet-delivered chronic pain self-management program: does agreement of treatment goals matter? J Pediatr Psychol 2017 Jul 1;42(6):657-666 [FREE Full text] [doi: 10.1093/jpepsy/jsw098] [Medline: 28008004]

166. Law EF, Fisher E, Howard WJ, Levy R, Ritterband L, Palermo TM. Longitudinal change in parent and child functioning after internet-delivered cognitive-behavioral therapy for chronic pain. Pain 2017 Oct;158(10):1992-2000 [FREE Full text] [doi: 10.1097/j.pain.0000000000000999] [Medline: 28777771]

167. Alberts NM, Law EF, Chen AT, Ritterband LM, Palermo TM. Treatment engagement in an internet-delivered cognitive behavioral program for pediatric chronic pain. Internet Interv 2018 Sep;13:67-72 [FREE Full text] [doi: 10.1016/j.invent.2018.07.005] [Medline: 30206521]

168. Narad ME, Minich N, Taylor HG, Kirkwood MW, Brown TM, Stancin T, et al. Effects of a web-based intervention on family functioning following pediatric traumatic brain injury. J Dev Behav Pediatr 2015;36(9):700-707 [FREE Full text] [doi: 10.1097/DBP.0000000000000208] [Medline: 26461100]

169. Wade S, Wolfe C, Brown T, Pestian JP. Putting the pieces together: preliminary efficacy of a web-based family intervention for children with traumatic brain injury. J Pediatr Psychol 2005;30(5):437-442. [doi: 10.1093/jpepsy/jsi067] [Medline: 15944171]

170. Wade SL, Carey J, Wolfe CR. An online family intervention to reduce parental distress following pediatric brain injury. J Consult Clin Psychol 2006 Jun;74(3):445-454. [doi: 10.1037/0022-006X.74.3.445] [Medline: 16822102]

171. Wade SL, Carey J, Wolfe CR. The efficacy of an online cognitive-behavioral family intervention in improving child behavior and social competence following pediatric brain injury. Rehabil Psychol 2006;51(3):179-189. [doi:

10.1037/0090-5550.51.3.179]

172. Wade SL, Walz NC, Carey JC, Williams KM. Preliminary efficacy of a web-based family problem-solving treatment program for adolescents with traumatic brain injury. J Head Trauma Rehabil 2008;23(6):369-377. [doi: 10.1097/01.HTR.0000341432.67251.48] [Medline: 19033829]

173. Wade SL, Walz NC, Carey JC, Williams KM. Brief report: description of feasibility and satisfaction findings from an innovative online family problem-solving intervention for adolescents following traumatic brain injury. J Pediatr Psychol 2009 Jun;34(5):517-522 [FREE Full text] [doi: 10.1093/jpepsy/jsn081] [Medline: 18667477]

174. Wade SL, Walz NC, Carey J, McMullen KM, Cass J, Mark E, et al. Effect on behavior problems of teen online problem-solving for adolescent traumatic brain injury. Pediatrics 2011 Oct;128(4):e947-e953 [FREE Full text] [doi: 10.1542/peds.2010-3721] [Medline: 21890828]

175. Wade SL, Walz NC, Carey J, McMullen KM, Cass J, Mark E, et al. A randomized trial of teen online problem solving: efficacy in improving caregiver outcomes after brain injury. Health Psychol 2012 Nov;31(6):767-776. [doi: 10.1037/a0028440] [Medline: 22746261]

176. Bjureberg J, Sahlin H, Hedman-Lagerlöf E, Gratz KL, Tull MT, Jokinen J, et al. Extending research on Emotion Regulation Individual Therapy for Adolescents (ERITA) with nonsuicidal self-injury disorder: open pilot trial and mediation analysis of a novel online version. BMC Psychiatry 2018 Oct 11;18(1):326 [FREE Full text] [doi: 10.1186/s12888-018-1885-6] [Medline: $\underline{\text { 30305103] }}$

177. le Marne FA, Butler S, Beavis E, Gill D, Bye AM. EpApp: development and evaluation of a smartphone/tablet app for adolescents with epilepsy. J Clin Neurosci 2018 Apr;50:214-220. [doi: 10.1016/j.jocn.2018.01.065] [Medline: 29422360]

178. Stinson JN, McGrath PJ, Hodnett ED, Feldman BM, Duffy CM, Huber AM, et al. An internet-based self-management program with telephone support for adolescents with arthritis: a pilot randomized controlled trial. J Rheumatol 2010 Sep;37(9):1944-1952. [doi: 10.3899/jrheum.091327] [Medline: 20595280]

179. Chih M, DuBenske LL, Hawkins RP, Brown RL, Dinauer SK, Cleary JF, et al. Communicating advanced cancer patients' symptoms via the internet: a pooled analysis of two randomized trials examining caregiver preparedness, physical burden, 
and negative mood. Palliat Med 2013 Jun;27(6):533-543 [FREE Full text] [doi: 10.1177/0269216312457213] [Medline: 22988042]

180. Gustafson DH, DuBenske LL, Atwood AK, Chih M, Johnson RA, McTavish F, et al. Reducing symptom distress in patients with advanced cancer using an e-alert system for caregivers: pooled analysis of two randomized clinical trials. J Med Internet Res 2017 Nov 14;19(11):e354 [FREE Full text] [doi: 10.2196/jmir.7466] [Medline: 29138131]

181. DuBenske LL, Gustafson DH, Namkoong K, Hawkins RP, Atwood AK, Brown RL, et al. CHESS improves cancer caregivers' burden and mood: results of an eHealth RCT. Health Psychol 2014 Oct;33(10):1261-1272 [FREE Full text] [doi: 10.1037/a0034216] [Medline: 24245838]

182. Gustafson DH, DuBenske LL, Namkoong K, Hawkins R, Chih M, Atwood AK, et al. An eHealth system supporting palliative care for patients with non-small cell lung cancer: a randomized trial. Cancer 2013 May 1;119(9):1744-1751 [FREE Full text] [doi: 10.1002/cncr.27939] [Medline: 23355273]

183. Fergus K, McLeod D, Carter W, Warner E, Gardner S, Granek L, et al. Development and pilot testing of an online intervention to support young couples' coping and adjustment to breast cancer. Eur J Cancer Care (Engl) 2014 Jul;23(4):481-492. [doi: 10.1111/ecc.12162] [Medline: 24472013]

184. Ianakieva I, Fergus K, Ahmad S, Pos A, Pereira A. A model of engagement promotion in a professionally facilitated online intervention for couples affected by breast cancer. J Marital Fam Ther 2016 Oct;42(4):701-715. [doi: 10.1111/jmft.12172] [Medline: 27234009]

185. Ianakieva I, Fergus K, Ahmad S, Pereira A, Stephen J, McLeod D, et al. Varying levels and types of engagement in an online relationship enhancement program for couples following breast cancer. J Couple Relatsh Ther 2019;18(1):22-43. [doi: 10.1080/15332691.2018.1546248]

186. Kim Y, Shaffer K, Mitchell H, Ting A, Carver C. DYADIC INTERNET-BASED HEALTH LIFESTYLE INTERVENTION FOR COLORECTAL CANCER SURVIVORS AND THEIR FAMILY MEMBERS: PILOT STUDY. In: PSYCHOSOMATIC MEDICINE. 2017 Presented at: American Psychosomatic Medicine Society; May 2017; Sevilla, Spain p. A87.

187. Mazzer C, Shaffer K, Kim Y. Healthy lifestyle behavior intervention for colorectal cancer survivors and their families: Pilot study. In: Annals of Behavioral Medicine. 2016 Presented at: Society of Behavioral Medicine; March-April 2016; Washington, DC, US p. S231.

188. Song L, Rini C, Deal A, Nielsen M, Chang H, Kinneer P, et al. Improving couples' quality of life through a Web-based prostate cancer education intervention. Oncol Nurs Forum 2015 Mar;42(2):183-192 [FREE Full text] [doi: 10.1188/15.ONF.183-192] [Medline: 25806885]

189. Vogel RI, Petzel SV, Cragg J, McClellan M, Chan D, Dickson E, et al. Development and pilot of an advance care planning website for women with ovarian cancer: a randomized controlled trial. Gynecol Oncol 2013 Nov;131(2):430-436 [FREE Full text] [doi: 10.1016/j.ygyno.2013.08.017] [Medline: 23988413]

190. Bryant J, Sanson-Fisher R, Stevenson W, Henskens F, Smits R. Build it, but will they come? Development and patient use of an online information tool designed to reduce psychosocial distress. PsychoOncology 2013;22:157. [doi: 10.1111/j.1099-1611.2013.3394]

191. Mayberry LS, Berg CA, Harper KJ, Osborn CY. The design, usability, and feasibility of a family-focused diabetes self-care support mHealth intervention for diverse, low-income adults with type 2 diabetes. J Diabetes Res 2016;2016:7586385 [FREE Full text] [doi: 10.1155/2016/7586385] [Medline: 27891524]

192. Milgrom J, Danaher BG, Gemmill AW, Holt C, Holt CJ, Seeley JR, et al. Internet cognitive behavioral therapy for women with postnatal depression: a randomized controlled trial of MumMoodBooster. J Med Internet Res 2016 Mar 7;18(3):e54 [FREE Full text] [doi: 10.2196/jmir.4993] [Medline: 26952645]

193. Kamwesiga JT, Eriksson GM, Tham K, Fors U, Ndiwalana A, von Koch L, et al. A feasibility study of a mobile phone supported family-centred ADL intervention, F@ce, after stroke in Uganda. Global Health 2018 Aug 15;14(1):82 [FREE Full text] [doi: 10.1186/s12992-018-0400-7] [Medline: 30111333]

194. Nilsson A, Magnusson K, Carlbring P, Andersson G, Gumpert CH. The development of an internet-based treatment for problem gamblers and concerned significant others: a pilot randomized controlled trial. J Gambl Stud 2018 Jun;34(2):539-559 [FREE Full text] [doi: 10.1007/s10899-017-9704-4] [Medline: 28699054]

195. Dew MA, Goycoolea JM, Harris RC, Lee A, Zomak R, Dunbar-Jacob J, et al. An internet-based intervention to improve psychosocial outcomes in heart transplant recipients and family caregivers: development and evaluation. J Heart Lung Transplant 2004 Jun;23(6):745-758. [doi: 10.1016/j.healun.2003.07.002] [Medline: 15366436]

196. Shaffer KM. OSF. 2019. Dyadic eHealth Interventions: A Systematic Scoping Review URL: osf.io/f3h5k

\section{Abbreviations}

eHealth: electronic health

PICOS: Population, Intervention, Comparison, Outcome, Study

RCT: randomized controlled trial 
Edited by G Eysenbach; submitted 15.07.19; peer-reviewed by E Kent, A Efthymiou, M Lozano-Lozano; comments to author 29.09.19; revised version received 08.11.19; accepted 19.12.19; published 04.03.20

Please cite as:

Shaffer KM, Tigershtrom A, Badr H, Benvengo S, Hernandez M, Ritterband LM

Dyadic Psychosocial eHealth Interventions: Systematic Scoping Review

$J$ Med Internet Res 2020;22(3):e15509

URL: https://www.jmir.org/2020/3/e15509

doi: $10.2196 / 15509$

PMID: 32130143

CKelly M M. Shaffer, Ashley Tigershtrom, Hoda Badr, Stephanie Benvengo, Marisol Hernandez, Lee M Ritterband. Originally published in the Journal of Medical Internet Research (http://www.jmir.org), 04.03.2020. This is an open-access article distributed under the terms of the Creative Commons Attribution License (https://creativecommons.org/licenses/by/4.0/), which permits unrestricted use, distribution, and reproduction in any medium, provided the original work, first published in the Journal of Medical Internet Research, is properly cited. The complete bibliographic information, a link to the original publication on http://www.jmir.org/, as well as this copyright and license information must be included. 